\title{
Early Paleozoic zircon ages of the Higher Himalayan Gneisses of the Everest region and their Pan-African/Proto-Himalayan orogenic signature
}

\author{
*Masaru Yoshida ${ }^{1,5}$, George E. Gehrels ${ }^{2}$, Bishal N. Upreti ${ }^{1,3,4}$, and Santa M. Rai ${ }^{5}$ \\ ${ }^{I}$ Gondwana Institute for Geology and Environment, Hashimoto, Japan, \\ ${ }^{2}$ Department of Geosciences, University of Arizona, Tucson, Arizona, USA, \\ ${ }^{3}$ Nepal Academy of Science and Technology, Kathmandu, Nepal, \\ ${ }^{4}$ Department of Geology, School of Mines, University of Zambia, Lusaka, Zambia, \\ ${ }^{5}$ Department of Geology, Tri-Chandra Campus, Tribhuvan University, Kathmandu, Nepal \\ *Corresponding author: gondwana@oregano.ocn.ne.jp
}

\begin{abstract}
The U-Pb analysis of zircons from two independent leucosome bodies belonging to the paragneiss of the Higher Himalayan Crystallines Sequence (HHCS) in the Everest region of eastern Nepal Himalaya was carried out using laser ablation-multicollector inductively coupled plasma-mass spectrometry (LA-MC-ICP-MS) at the University of Arizona, Tucson, USA. The analysis of zircons from sample 07EVT3 forms a discordia with upper and lower intercepts at 478 \pm 25 and 21.5 \pm 4.1 Ma with concordant ages of $488.5 \pm 9.2$ and $20.9 \pm 0.9$ Ma for cores and rims, respectively. Similarly, the analysis of zircons from sample U1206 forms a discordia with upper and lower intercepts at $515 \pm 20$ and $34.8 \pm 2.7 \mathrm{Ma}$, and provides concordant ages of $463.9 \pm 10.9$ and $24.6 \pm 0.6 \mathrm{Ma}$ for cores and rims, respectively. No inherited zircon grains with older ages were found indicating that almost all these zircons must have formed along with the leucosomes during the ca. 500 Ma metamorphism of the protoliths. The high U/Th ratio, i.e. average 11.0 for zircons from sample 07EVT3 and 253.6 for sample U1206 also support a metamorphic origin of the zircons. The occurrences of zircons in the ca. 500 Ma leucosomes in the HHCS strongly points that rocks in the Himalayan area had undergone to a high-grade metamorphism during the late Pan-African time. We call this metamorphism as the Protohimalayan metamorphism. More studies along this line will help to better understand and constrain the Pan-African orogenic history of the Proto-Himalayan Orogen within the Peri-Gondwana Orogenic terrains.
\end{abstract}

Keywords: Higher Himalayan Crystallines Sequence, Protohimalayan metamorphism, Everest region, U-Pb analysis of zircons

Paper Received: 31 Mar 2019

Paper Accepted: 5 May 2019

\section{INTRODUCTION}

The Himalayan orogeny is the result of the Cenozoic collision of the Indian plate against the Eurasian plate. However, there are several lines of evidences in stratigraphy, magmatism and metamorphism suggesting that the proto-Himalayan belt suffered some orogenic events during the early Paleozoic time in the northern margin of East Gondwana (e. g., Valdiya, 1995; Gehrels et al., 2003; Yoshida and Upreti, 2006; Yoshida and Upreti, 2007; Yoshida et al., 2006; Cawood et al., 2007).

We found several evidences of tectonic and metamorphic events prior to the Miocene main Himalayan tectonometamorphism in the Everest area of eastern Nepal. A preliminary geochronological study of zircons from leucosomes of two gneiss samples of the Higher Himalayan Crystalline Sequence provided the evidence of early Paleozoic high-grade metamorphism, which is one of rare direct evidences of Early Paleozoic high-grade metamorphism in the Himalayan Belt, that we call the Proto-Himalayan metamorphism.

The ca. $2500 \mathrm{~km}$ long and 300-400 km wide Himalayan
Orogen is divided from south to north into (i) the Gangetic Alluvium Zone (Quaternary foreland basin), (ii) the SubHimalayan or Siwalik Zone (Neogene foreland basin), (iii) the Lesser Himalayan Zone (mostly Proterozoic metasediments), (iv) the Higher Himalayan Zone (high-grade gneisses, schists and marbles), and (v) the Tibetan-Tethys Zone (PaleozoicMesozoic continental margin sediments).

The Main Frontal Thrust (MFT), which is the southernmost Himalayan thrust, separates the Gangetic Alluvium Zone from the Sub-Himalayan Zone, the Main Boundary Thrust (MBT) separates the Sub-Himalayan Zone from the Lesser Himalayan Zone and the Main Central Thrust (MCT) separates the Lesser Himalayan Zone from the Higher Himalayan Zone, all the thrusts dipping to the north. On the other hand, the Higher Himalayan Zone is separated from the Tibetan - Tethys Zone by a north dipping normal fault composing the South Tibetan Detachment System (STDS).

This major architectural framework of the Himalaya is quite uniform with major geologic zones running parallel throughout its length. Except for the Gangetic Alluvium and 


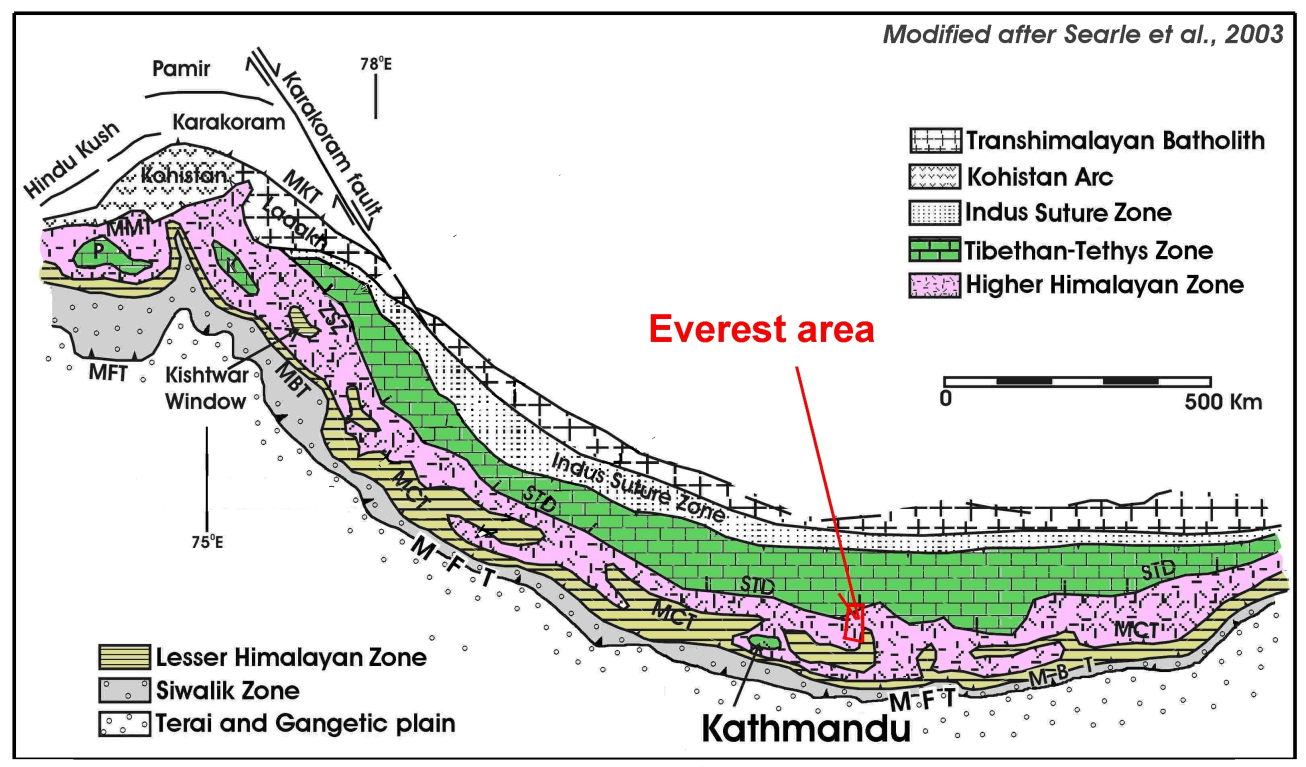

Fig. 1: Geologic outline of the Himalaya and the location of the study area

Tibetan-Tethys zones, all the other three Himalayan zones are thrust southward along the regional thrusts, as a result of the collision tectonics between the Indian and Eurasian plates. The Everest region is situated on the eastern part of the Nepal Himalaya and the present study area is mostly composed of the gneisses of the Higher Himalayan Zone (Fig. 1).

\section{GEOLOGY OF THE EVEREST AREA}

The Himalayan orogen is composed of five geotectonic zones as mentioned above which are bounded by north- dipping faults. Within the present study area in the Everest region (Fig. 2), the Higher Himalayan Zone occupies most of the area whereas only a small part is covered by the Lesser Himalayan Zone to the south, and just a small area to the north is occupied by the Tibetan-Tethys Zone (Lombardo et al., 1993; Schelling, 1999; Searle et al., 2003; Rai et al., 2010; Yoshida et al., 2011). The nomenclature of geologic units, general geology, petrography and metamorphism of the present area are given in Rai et al. (2010), to which the description below generally follows.

\section{The Lesser Himalayan Sequence (LHS)}

The major part of the rocks occurring in the Lesser Himalayan Zone is collectively called the Lesser Himalayan Sequence (LHS) which were deposited during the Late

Fig. 2: Geological map of the Everest area (Rai et al., 2010). Tibetan-Tethys Zone: Mount Jolmo Lungma Formation (MJF) and North Col Formation (NCF) including the Yellow Band, Miocene leucogranite (LG), Higher Himalayan Crystalline Sequence: Rongbuk Formation (RBF), Namche Migmatites (NCM) and Barun Gneiss (BRG), Lesser Himalaya Zone: Gudel Phyllite (GP) Melung-Sallery Augen Gneiss (MSA) and Kuncha Formation (KC). x x: Tertiary Leucogranite, dark circles: Locations of analyzed samples.

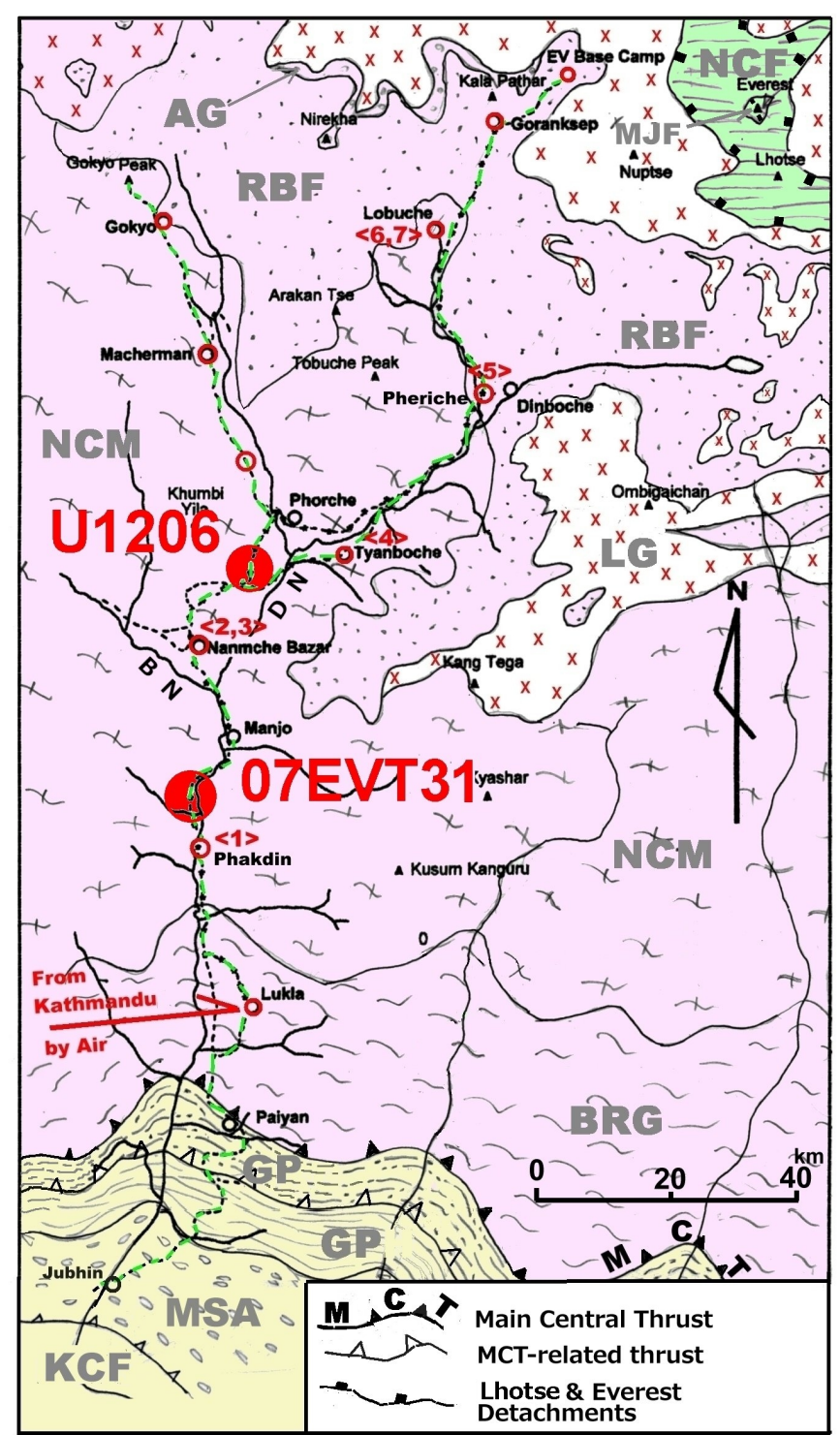


Paleoproterozoic to early Paleozoic Eras. With unconformities, the LHS are partly capped by much younger rocks including the upper Paleozoic to lower Cenozoic Gondwanas and further younger Cenozoic sediments. The LHS is composed mostly of metasediments, with several intercalated bodies of augen gneisses usually near the uppermost horizon.

In the present study area, the Kuncha Formation (KCF, also called the Kusma Formation by Goscombe et al., 2006), the Melung Salleri Augen Gneiss (MSA, also called the Ulleri Formation by Goscombe et al., 2006) and the Gudel Phyllite (GP, also called the Seti Formation by Goscombe et al., 2006) from the lowest (south) to the uppermost formations (north) belong to the LHS. Close to the MCT, the LHS rocks show intense shearing effect obviously related to the movement along the MCT, that delineates the northern margin of the LHS. Below the MCT there are several faults occurring within the LHS of the present study area.

The KCF has undergone a very low-grade metamorphism and characteristically carries sericite phyllite and chlorite phyllite. The MSA is originally biotite granite, which suffered intense shearing and alteration including saussulitization of feldspars and weak chloritization of biotite. The MSA is correlated with the Ulleri Augen Gneiss in central Nepal Himalaya. The GP is characterized by two mica-garnet-staurolite graphite schist and chlorite-sericite-biotite-quartz-albite schist. Tourmaline leucogranite veins are found to develop along shear planes of rocks of the GP near the MCT. At a lower horizon of the GP, chlorite phyllonite and graphite phyllonite occur clearly indicating the late shearing effect of MCT.

The metamorphic grade of the LHS thus obviously increases towards the structural upper horizon closer to the MCT. According to Goscombe et al. (2006), the peak metamorphic conditions of the footwall rocks of the MCT (their Higher Himalayan Thrust) are 510o C and 7.5 $\pm 1.9 \mathrm{~kb}$ in average. All the metamorphic features of the upper part of the LHS are regarded to be related to the Miocene MCT activity.

\section{The Higher Himalayan Crystalline Sequence (HHCS)}

In the study area, The HHCS is represented by three rock units (from bottom to top) - the Barun Gneiss, the Namche Migmatites, and the Rongbuk Formation. Rai et al. (2010) pointed out that the Barun Gneiss could be correlated with the Formation I of the central Nepal, a part of the Namche Migmatites with the Formation II, and the augen gneiss unit occurring in the upper part of the Rongbuk Formation with the Formation III of Le Fort (1975).

The Barun Gneiss: It consists of garnet-biotite gneiss, feldspathic gneiss and granitic gneiss. All these rocks contain sillimanite with cordierite and spinel, which partly replace older crystals of kyanite. Kyanite and muscovite commonly occur in rocks of the lower horizon, i.e., near the MCT. Biotite gneiss occurs with or without garnet and sillimanite. Locally, folded calcic gneiss, quartzite and marble layers occur mostly in the upper part. The Barun Gneiss as a whole could be comparable with the Formation I in central Nepal (Le Fort, 1975).

The Namche Migmatites: It begins with the appearance of migmatitic gneiss north of Jorsalle. The lower part of this rock unit is migmatitic biotite gneiss with or without sillimanite. Around Namche Bazaar, it is composed of granitic orthogneiss including augen gneiss and granitic gneiss associated with minor amount of paragneisses composed mostly of migmatitic biotite gneiss. These rocks mostly contain sillimanite in varying amounts. North of Tyanboche, the gneisses are generally biotite gneiss carrying amphibole. Rarely calcareous gneiss also occurs with marble layers. The Namche Migmatites could be compared with the Formation II in central Nepal (Le Fort, 1975) except the orthogneiss bodies.

The Rongbuk Formation: It consists of para-schist and paragneisses with abundant biotite and with variable amount of fibrolite sillimanite. Near the uppermost horizon of this formation an augen gneiss unit is exposed which is similar to the Formation III in Central Nepal (Le Fort, 1975).

The protolith of the HHCS is normally considered to be the sedimentary sequence deposited at the northern margin of the Indian subcontinent (e. g., Myrow et al., 2003, 2006). The age of the deposition of the protoliths was long considered to be mostly Neoproterozoic, but as pointed out by Myrow et al. (2009) it mostly belongs to the early to middle Cambrian time. The metamorphism of the HHCS is of granulite facies to amphibolite facies, generally considered to have taken place at ca. 24-20 Ma as the main Himalayan metamorphism, although earlier and later metamorphisms have been identified or estimated by several authors as mentioned below.

\section{The Tibetan-Tethys Sedimentary Sequence (TTSS)}

The rocks belonging to the Tibetan-Tethys Zone are known as the Tibetan-Tethys Sedimentary Sequence (TTSS). They range in age mostly from Cambrian to Cretaceous. In the present study area, the rocks of the TTSS occur only at very high altitude and therefore, we could not make any direct field survey on the TTSS. We could only view the TTSS from a distance lying above the Rongbuk Formation with leucogranite sills at the boundary. The base of the TTSS is represented by the North Col Formation including the Yellow Band (NCF, Lower to Middle Cambrian, Myrow et al., 2009) characterized by upper-middle greenschist facies semischist-phyllite. The overlying Jolmo Lungma Formation (JLF, Lower to Middle Ordovician, Yin and Kuo, 1978) is composed of metasediments represented by mostly crystalline limestone. The base of the TTSS is delineated by the Lhotse Detachment, the lower strand of the STDS and the JLF and the NCF are bounded by the Everest Detachment, the upper strand of the STDS (Sakai et al., 2005) along which a Tertiary leucogranite sill has intruded.

\section{Miocene Tourmaline Leucogranite (TLG)}

Large intrusive masses of Tertiary tourmaline leucogranite are exposed mostly around the STDS. In the Everest region, it is known as the Everest Leucogranite (Bortolami et al., 1983). 
It is a muscovite-biotite- tourmaline leucogranite dated as Miocene in age. Smaller granitic bodies of the TLG intrude most geologic units of the TTSS. The rocks of the TLG contain quartz, microcline/orthoclase and plagioclase, with varying amount of tourmaline, muscovite, biotite and garnet, occasionally associate with sillimanite, cordierite, andalusite, apatite, monazite and zircon (Searle et al., 2003). The leucogranitic intrusions of similar composition and age are well developed throughout the HHCS as dykes, straight and arteritic veins, pools and pods, but they become less common in the lower horizon. The TLG in the Everest region ranges in age from 22 to $20 \mathrm{Ma}$ (Simpson et al., 2000).

The TLG was not observed to occur within the TTSS in the study area. It could not be seen even on the western slope of Mt. Everest when viewed with binoculars, although the leucogranite dykes and veins occur within the equivalent strata in the Nyalam area of China ca. $80 \mathrm{~km}$ northwest from Mt. Everest (Goscombe et al., 2006). However, Sakai et al. (2005) reported the occurrence of the leucogranite within the JLF on the southwest slope of the Mt. Everest.

\section{Early Paleozoic and older Granites}

Early Paleozoic and older granitic rocks occur widely in the Himalayan Orogen (Le Fort, 1975). Granitic rocks with ages of ca. $500 \pm 25 \mathrm{Ma}$ occur at various structural levels within the HHCS (Le Fort et al., 1986). In the eastern and central Nepal Himalaya, thick units of augen gneiss of the early Paleozoic in age occur generally at the uppermost horizon of the HHCS that is correlated with the Formation III in central Himalaya identified by Le Fort (1975).

In the Everest region, granitic orthogneiss forming a large part of the Namche Migmatites are also regarded to belong the early Paleozoic granites, and small bodies of similar orthogneiss also occur within the Barun Gneiss. The emplacement age is found to be at 465 - $470 \mathrm{Ma}$ in the EverestMakalu region based on $\mathrm{U}-\mathrm{Pb}$ dating of zircon and zenotime (Viskupic and Hodges, 2001).

The Melung-Salleri Augen Gneiss occurs at the upper horizon of the LHS. The augen gneiss of similar lithology and occurrence are also widely found all along the Nepal Himalaya mostly at a similar structural level. One of these rocks, the Ulleri Augen Gneiss in central Himalaya is dated at ca $1850 \mathrm{Ma}$ (Robinson et al., 2001).

\section{STRUCTURES}

\section{Geologic Structures}

The geologic architecture of the Everest region including the study area is generally younging northward as mentioned above, although complex and multiphase folds develop. The oldest LHS occurs to the southmost, the HHCS next, and the youngest TTSS to the northmost (e.g., Carosi et al., 1999; Searle et al., 2003). Mesoscopic bedding panes, however, are quite variable in the region as seen on the structure map by Carosi et al. (1999).

The Main Central Thrust (MCT) delineates the LHSHHCS boundary, whereas the South Tibetan Detachment System (STDS) marks the TTSS-HHCS boundary. This structural architecture could also be very well correlated with other parts of the orogen (Myrow et al., 2003; Yoshida and Upreti, 2006; Goscombe et al., 2006; Searle et al., 2007; Myrow et al., 2009) and is essentially extending all along the Himalayan Orogen.

Goscombe et al. (2006) have identified the MCT of the present study as the Himalayan Unconformity and delineated their MCT a few kilometers south from our MCT. Their observation is corroborated by recent finding of the Himalayan Disconformity in Central Nepal by Montomoli et al. (2013).

Structurally, the study area is composed of two different zones, the HHCS zone in the north and the MCT zone in the south. The boundary lies around Paiya village, about $1 \mathrm{~km}$ to the north of the MCT. The MCT zone includes the lowest horizon of the Barun Gneiss and the upper horizon of the LHS.

Major NE-SW and NW-SE close to open folds are reported to develop in the Everest region including the study area (Carosi et al., 1999). Small folds of various interlimb angles and orientations develop throughout the area as mentioned below.

In the HHCS zone, rocks are commonly ordinary gneisses carrying variably trending $S$ and L structures. Regarding the directions of bedding and foliation, northeasterly intermediate dips are dominant in the southern half, and in the area north of Phorche, south easterly moderate dips commonly occur (Fig. 3 ). The general structure of the HHCS zone above appears to be explained by the late stage two major foldings mentioned above.

Rocks of the MCT zone are strongly sheared and the splanes gently dip to north, and lineations plunge gently northnortheast.

\section{The Main Central Thrust (MCT)}

We have delineated the MCT, the boundary between the HHCS and LHS, between Kare and Kharte villages about $5 \mathrm{~km}$ south of Lukla where the southern outcrops of gneisses and migmatites of the Barun Gneiss of the HHCS give way to schist/phyllite, belonging to the Gudel Phyllite of the LHS. Our location of the MCT placed at the uppermost boundary of the Gudel Phyllite coincides with that given by Akiba et al. (1973), and close to the High Himalayan Unconformity of Goscombe et al. (2006), who delineated the MCT $1 \mathrm{~km}$ south of our MCT.

The structural-metamorphic effect of the movement along the MCT (associated with the extrusion of HHCS) has vertically affected a thick zone involving the upper horizon of the LHS and a significant part of the lower sequence of the 


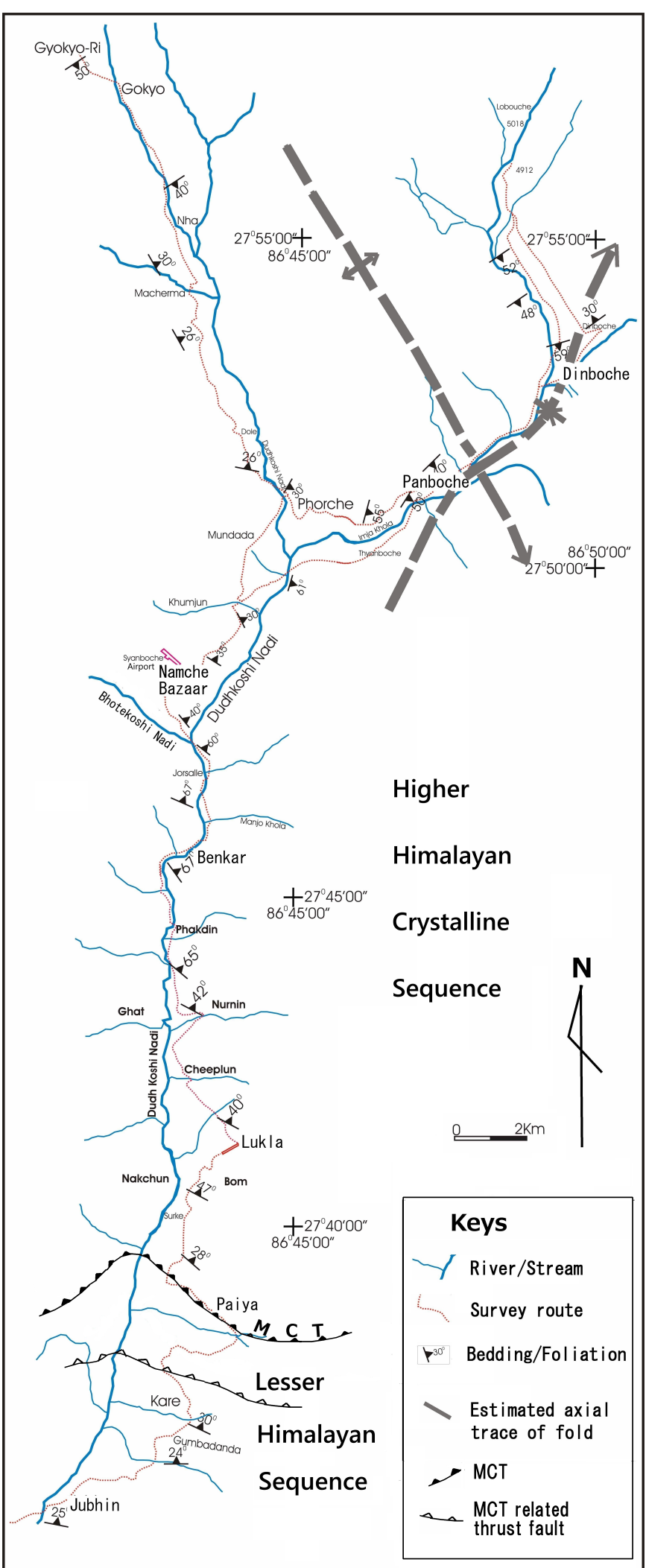

Fig. 3: Structures of the area along the Dudhukoshi valley, south of Mt Everest. Possible axial traces of major NW-SE folds are delineated referring Carosi et al. (1999)
HHCS. It includes the wide development of late schistosity associated with amphibolite facies mineral assemblages in the MCT zone as well as the development of shear planes in the HHCS zone characterized by the presence of sillimanite. The later metamorphism related with the MCT activity includes the phyllonitization in the Gudel Phyllite, and shear planes development associated with chlorite-sericite in both LHS and HHCS. Goscombe et al. (2006) estimated the age of the MCT activity to range from 22-18 Ma to 9-8 Ma from the top to the bottom within the MCT zone (area of the Gudel Phyllite and the lower part of the Barun Gneiss of our study).

\section{The South Tibetan Detachment System (STDS)}

The South Tibetan Detachment System (STDS) is a low angle normal fault that forms the boundary between the TTSS above and the HHCS below (e. g., Searle et al., 2003). In the Everest region, the STDS is split into two strands: i) the Everest Detachment (ED) forming the upper strand and ii) the Lhotse Detachment (LD) forming the lower one. The ED lies at the boundary between the overlying Jolmo Lungma Formation and the underlying Yellow Band. The LD, on the other hand, lies at the boundary between the North Col Formation above and the Rongbuk Formation of the HHCS below.

The detachment fault is generally considered to have formed as a result of the Eo-Himalayan thrust tectonics, at around ca. 35 - $30 \mathrm{Ma}$ (Goscombe et al., 2006). The reactivation of the STDS is considered to have occurred around ca. $22-17$ Ma to ca. 11 Ma. (e.g., Edwards and Harrison, 1997), that appears to have affected the lower horizon of the TTSS by strong shearing which resulted into the formation of the mylonitic, sheared and cleavage structures. Carosi et al. (1999) reported the widespread development of extensional structures, such as small folds, shear planes and crenulation cleavages within middle to upper horizons of the HHCS, related to the STDS movement. Sakai et al. (2005) found the fission track ages of ca. 14.4 Ma for both zircon and apatite grains from rocks of the Yellow Band and pointed out a very rapid cooling of the rocks down to ca. $130 \mathrm{oC} \pm 30 \mathrm{oC}$ at that period. This age, therefore, could reflect the major detachment movement event along the STDS.

\section{Mesoscopic structures}

The gneisses belonging to the HHCS carry a variety of s-structures including bedded, banded, foliated (identified by the development of leaf-shaped aggregates of minerals), schistose (identified by the lattice preferred orientation of minerals), or cleaved (identified by micro-spaced cleavages) structures. Mesoscopic to microscopic intrafolial isoclinal folds of thin bands are also often observed. Mesoscopic tight to isoclinals folds, boudinage and micro-meso shear band well develop throughout the HHCS of the study area. Crenulation folds as well as axial plane foliation/schistosity are also observed sporadically. 
L-structures observed in the present study include hinges of small folds either directly observed or stereographically estimated, stretching lineation composed of elongation of minerals or mineral aggregates, microfold/undulation/crenulation of s-planes, and intersection of 2 s-planes such as bedding and schistosity.

These structures are associated with growth of minerals reflecting metamorphism of various stages as well as the development of granitic and leucogranitic material as mentioned below, and thus very important to resolve the succession of metamorphism in the study area. However, confining to the objectives of the present study, we mainly focus on the timing of the early leucosomes as discussed below as well as elsewhere in this paper.

Thin bandings composed of the alternation of biotiterich and quartz-feldspar-rich thin layers sometimes associated with thin leucosomes pools, often show intrafolial rootless isoclinal and small isoclinal folds (Figs. 4a-B, E). The intrafolial as well as small isoclinal folds are folded by small isoclinaltight-close-open folds, which often carry schistosity parallel to the axial surface. The schistosity is composed mostly of biotite and sometimes associated with flattened potash feldspar porphyroblast and/or elongated sillimanite (Figs. 4a-E, 4b-A, $\mathrm{B}, \mathrm{C}$ ), and hence are regarded to have formed in synchronous with the main Himalayan metamorphism.

Small open - gentle folds belong to further later generation. At an outcrop east of Panboche, tourmaline muscovite pegmatite is folded along with foliated gneisses with flattened potash feldspar porphyroblasts along the axial surface of small gentle folds, and the pegmatite carries cleavage parallel to the fold axis (Fig. 4b-D). Slip planes associated with biotite and sillimanite develop sporadically in all the study area. They cut the close-tight folds and also, cut penetrative schistosity (Fig. 4b-E).

\section{Variation in the orientation of $S$ and $L$ structures}

In the HHCS zone of the present study, mesoscopic structures are quite dispersed, having gentle-intermediate angle of dips toward southeast-east-northeast and north. The 1structures, on the other hand, have a prominent trend of NNENNW with gentle plunges (Figs. 3, 5a, b). The wide scatter of s-panes could mostly be explained by a late but major NE-SW and NW-SE large folds which are shown to develop in the Everest region by Carosi et al. (1999). A general conformity of the dispersed distributions of bedding and foliation (including banding, foliation and schistosity) may be a reflection that most foliations were formed during the earlier folding events and together re-oriented during the later major folding events.

A wide dispersal of lineations in the HHCS zone suggests that they were formed earlier than the major younger folding events. A small number of observations of fold axial surfaces show that they dip variably but generally strike NNE-SSW and NW-SE and hinges of small folds also prominently run NNESSSW and NW-SE with gentle plunges. It is possible that these small folds are associated with the major F2a and F2b folds of Carosi et al. (1999). Since the major foldings of the area are reported to be broadly synchronous with the development of the STDS and hence with the main Himalayan metamorphism, the association of schistosity composed of biotite, sillimanite and/or flattening of potash feldspar is considered to suggest that the schistosity formed during the main Himalayan metamorphism. The distribution of some lineation directions conforms to those of fold hinges and could have formed under the tectonics that formed the folds.

$\mathrm{S}$ - and l-structures are relatively simple in the MCT zone. Bedding planes and foliations are generally inclined moderately to gently to the north, appearing to have a â maxima plunging moderately NNE. The stereograms also show that the â maxima of bedding planes seem to have a little steeper angle than that of foliations.

The existing orientation pattern of beddings in the MCT zone could be attributed to the dragging of variously oriented bedding planes (including folds) by the south-southwesterly shearing effect of the MCT, and that of foliations is considered to mostly show the shearing panes related to the MCT activity.

Lineations in the MCT zone show a good concentration of NNE trend with a gentle plunge, which generally conforms with the estimated â maxima of foliations, but not of beddings. These lineations are regarded to have been formed as a result of the shearing effect caused by the movement of the MCT, and show the direction of the shearing movement.

All the above observations could be interpreted that the MCT zone also suffered complex and multiple foldings as exemplified by the distribution of $\mathrm{S}$ and $\mathrm{L}$ structures in the HHCS zone, and that later strong shearing activity of MCT affected almost all pre-existent $\mathrm{S}$ and $\mathrm{L}$ structures, either reorienting them or forming new ones.

\section{METAMORPHISM, MIGMATIZATION AND GRANITIC INTRUSIONS}

\section{Cenozoic Himalayan metamorphism}

Metamorphism in the Himalayan belt has commonly been understood to be composed of the (i) ultra-high $\mathrm{P}$ metamorphism at ca $45 \mathrm{Ma}$, (ii) the high-P Barrovian type EoHimalayan metamorphism at ca $33 \mathrm{Ma}$, (iii) the medium to lowP Miocene main Himalayan metamorphism at ca 22Ma, and (iv) lower grade metamorphism related to the late activity of MCT as well as STDS at ca 14 Ma and younger. As a whole, all of these metamorphic events were caused by the subduction of the Indian plate below Tibet, stacking and buckling of the LHS and TTSS as a result of the collision of the two continents, followed by a later extrusion of hot HHCS at the boundary between the LHS and TTSS, and finally later intermittent activities of STDS and MCT as summarized by Carosi et al. (1999) and Sakai et al. (2005). 


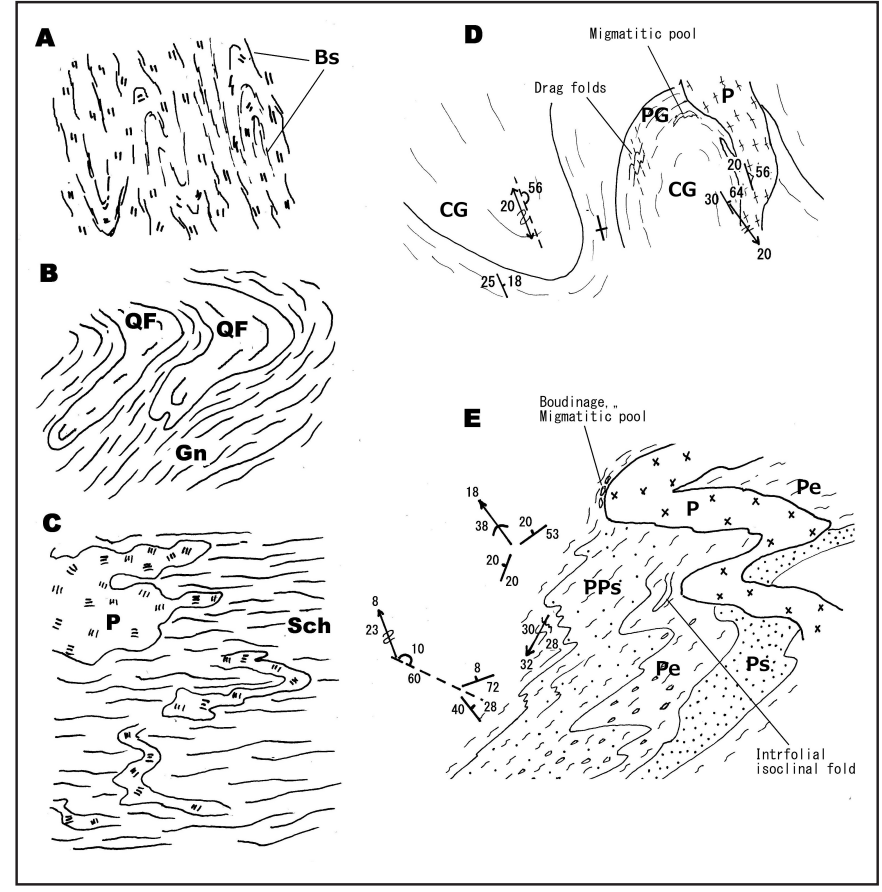

(a)

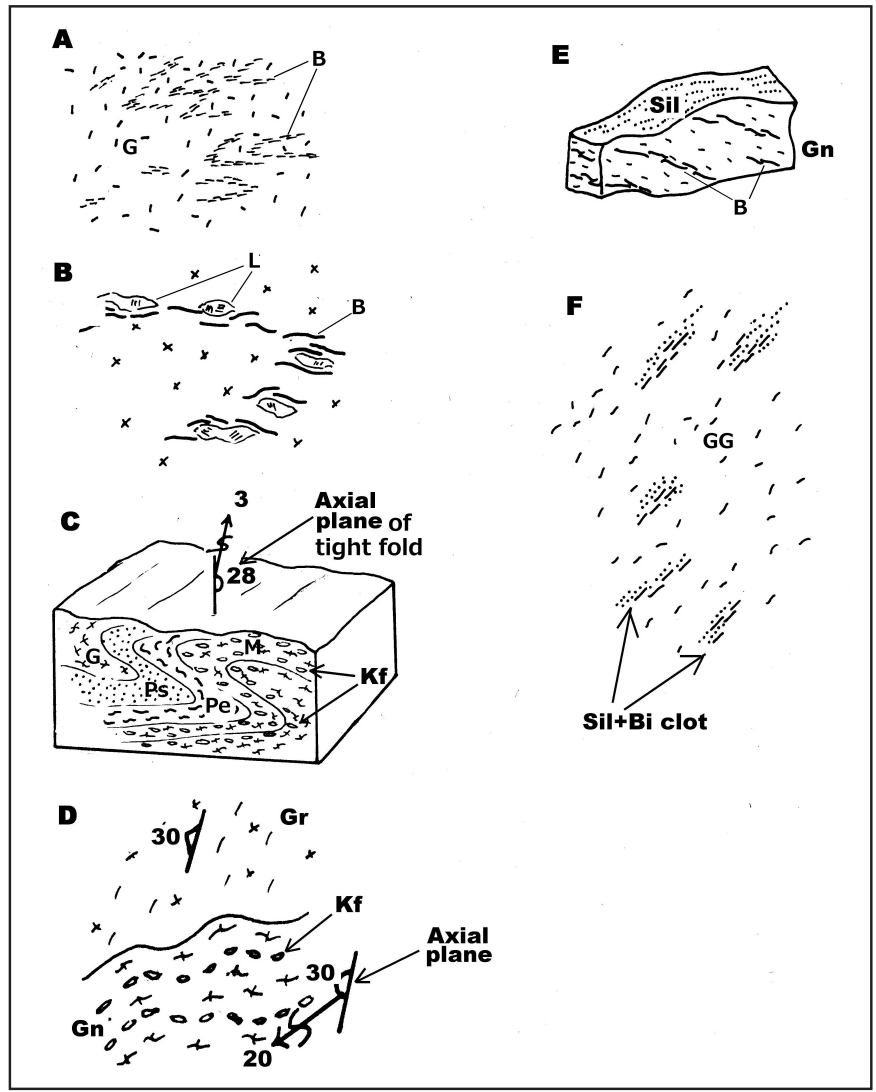

(b)

Fig. 4: (a) Earlier structures and leucosomes in HHCS rocks: A. Migmatitic gneiss with palimpsestic isoclinal intrafolial folds shown by biotite-rich seams (Bs) possibly derived from strong shearing/myonitization of augen gneiss. Location: South of the Bhotekoshi-Dudhukoshi confluence. B. Leucosome pool showing isoclinal folds and refolded by a close fold. QF: Leucosome, Gn: Banded biotite gneiss. Location: South of the Bhotekoshi-Dudhukoshi confluence. C. Biotite schist (Sch) with sporadic potash feldspar-rich leucosomes $(P)$ which are folded with axial surface parallel to the schistosity. Location: At a quarry northwest of Namche Bazaar. D. Isocinally folded banded calc-gneiss (CG) associated with psamopelitic gneiss (PG) which are cut across by a pegmatite dyke (P) which carry schistosity parallel to the schistosity of the host gneiss. The thinly banded gneiss with thin migmatitic bands and pools are together folded. The sketch is a southeasterly facing nearly vertical wall. Location: West of Benkar, stop G-14 of Yoshida et al., 2011. E. Folded biotite pegmatite (P) across banded paragneiss composed of pelitic (Pel), psamo-pelitic (PPs) and psammitic (Ps) bands. The paragneiss carry isoclinal intrafolial to small folds and suffered close-tight folds. Potash feldspar porphyrobasts are fattened parallel to the axial surface of the tight-close folds. Location: East of Panboche, stop G-37 of Yoshida et al. (2011).

(b): Later structures developed in HHCS rocks: A. Migmatitic granite (G) carries palimpsestic tight folds which is composed of biotite-rich bands (B). Biotite crystals of the bands are mostly alined parallel to the axial plane of the fold. Location: A boulder on the lower terrace of the Bhotekoshi-Dudhkoshi confluence B. Migmatitic granite carrying palimpsestic tightisoclinal folds which is composed of elongate pods of leucosomes $(\mathrm{L})$ mostly composed of potash feldspar aggregates and coarse crystals of biotite (B). The elongation of the aggregates and biotite crystals are aligned parallel to the supposed axial plane of the fold. Location: A boulder on the lower terrace of the Bhotekoshi-Dudhkoshi confluence. bC. Banded gneiss composed of granitic (G), psammitic (Ps), and pelitic (Pe) and migmatitic (M) bands. The gneiss is tightly folded with the development of schistosity parallel to the axial surface of the fold. Banding of the gneiss including the potash feldspar porphyroblast-rich layer (M) are folded, however, the porphyroblasts (Kf) are flattened parallel to the axial surface of the fold. Location: East of Panboche, stop 35 of Yoshida et al. (2011). D. Banded pelitic/psamo-pelitic gneiss with potash feldspar porphyrobasts (Kf) wnd suffered gentle fold. Tourmaline muscovite pegmatite (Gr) intruded parallel to the banding. The pegmatite is not foliated, but carry cleavage parallels with the axial plane of the folding of the gneiss. Location: East of Panboche, stop G36 of Yoshida et al. (2011). E. Foliated biotite gneissose granite (Gn) with vague thin biotite-rich bands (B). A slip plane associated with lineated sillimanite (Sil) develops cutting across the foliation. Location: At a quarry northwest of Namche Bazaar. F. Biotite gneissose granite (GG) carry vague foliation composed of clots of coarse crystals of biotite and sillimanite. Location: A quarry northwest of Namche Bazaar. 


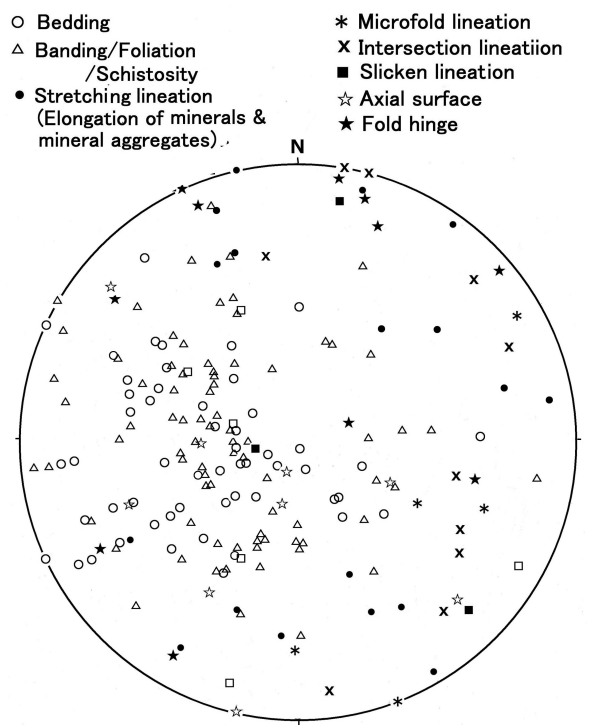

(a)

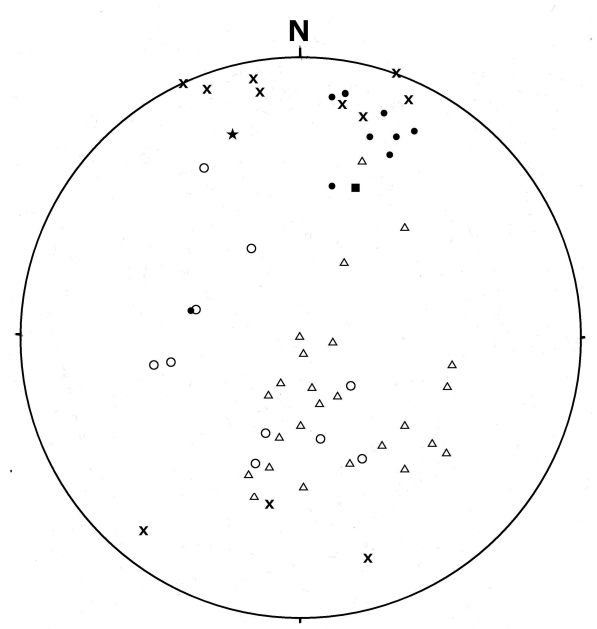

(b)

Fig. 5: (a) Equal area stereographic projection of $L$ and $S$ structures in the HHCS zone, and (b) Equal area stereographic projection of $L$ and $S$ structures in the MCT zone.

Recent observation and review by Carosi et al. (2016), however, appear to suggest that the ultra-high metamorphism and the Dalradian type metamorphism are a continuous event, and that the extrusion (or exhumation) of the HHCS took place several times since ca $40 \mathrm{Ma}$ to ca $11 \mathrm{Ma}$.

Our observations in the Dudhukoshi Valley area appear to conform with the above, except that we could not detect the evidence of the ultra-high P metamorphism, and instead, found the indication of migmatization having taken place earlier than the main Himalayan metamorphisms. Some observations are given below.

In the Everest region including the study area, the North Col Formation (NCF) and Yellow Band had undergone upper greenschist facies to greenschist facies metamorphism, but the overlying Jolmo Lungma Formation (JLF) reached only to a lower greenschist facies (Sakai et al., 2005; Goscombe et al., 2006; Rai et al., 2010). The metamorphism of the Yellow Band could either be related to the thrust movement which caused of the Eo-Himalayan metamorphism mentioned below, and /or that of the Miocene STDS movement. Sakai et al. (2005) reported Ar-Ar ages of ca 33.3 Ma and 24.5 Ma on muscovite and Rb$\mathrm{Sr}$ whole rock and muscovite rich and poor fractions isochron age of ca $40 \mathrm{Ma}$. They considered that the ca $40 \mathrm{Ma}$ age of muscovite may reflect the metamorphism caused by the burial and stacking of the TTSS along with LHS, and the ca $33.3 \mathrm{Ma}$ and ca 24.5 Ma point to the Eo-Himalayan and Neo-Himalayan metamorphisms, respectively.

In the HHCS, rocks of the lowest horizon of the Barun Gneiss include garnet-biotite gneiss with muscovite, feldspathic gneiss and granitic augen gneiss, all of which contain prismatic sillimanite with cordierite and spinel, partly replacing older crystals of kyanite. The gneisses of the upper horizon of the Barun Gneiss and all gneisses of the Namche Migmatites show granulite-high amphibolite facies mineral assemblages of sillimanite-garnet- biotite-potash feldspar-plagioclase-quartz, without muscovite and kyanite. Mineral assemblages of the Rongbuk Formation are generally similar to those found in the Namche Migmatites, but sillimanite is fibrolite and muscovite becomes common in gneisses occurring in the upper horizon (Rai et al., 2010). Thus, the metamorphic grade of the HHCS seems to decrease both towards the bottom and the top of the rock units. However, based on the intensity of migmatization, the Namche Migmatites shows the highest grade throughout the HHCS, as the migmatitic granitic material is strongly and widely developed in these rocks.

Throughout the HHCS, shear planes associated with aggregates of fibrous sillimanite, often associated with biotite and muscovite, develop sporadically. This could be the reflection of the activity of the MCT during the later stage of the main Himalayan metamorphism. In the present study, we could not identify the earlier ultra-high-pressure and high-pressure metamorphisms that have been reported to have developed throughout the Himalayan orogen (Kaneko et al., 2003; Goscombe et al., 2006). The metamorphism related to the MCT activity as described above and an extensive development of the granulite-amphibolite facies mineral assemblages as a whole represent the main Himalayan metamorphism.

Rocks of the LHS below the MCT suffered greenschist to lower amphibolite facies metamorphism with the increasing temperature conditions towards north (Rai et al., 2010), i.e., structurally and stratigraphically upward. The rocks of the LHS are mainly composed of garnet-chlorite-muscovite phyllite and chlorite-muscovite phyllite in the lowest horizon (Kuncha Formation), highly sheared chlorite biotite orthogneiss in the middle (Melung-Salleri Augen Gneiss), and two mica garnet schist, two mica staurolite garnet schist and two mica garnet gneiss in the uppermost horizon (Gudel Phyllite). The petrographic characteristics of the LHS rocks above, coupled with the occurrence of relict kyanite in HHCS rocks mentioned above could point to the development of a regional Barrovian type metamorphism in the LHS along with the HHCS earlier than the main Himalayan medium-low P metamorphism. Just 
south of the MCT, chlorite phyllonite and graphite phyllonite occur, reflecting the inhomogeneous activity of the MCT under the greenschist or lower conditions in later times. Tourmalinebearing leucogranite veins often develop within the rocks of the upper horizon of the Gudel Phyllite (Rai et al., 2010).

\section{Migmatization and granitic-leucogranitic activities}

Occurrence of granitic pools and leucosomes: Granitic (including leucosome) pools with or without garnets commonly occur in the Barun Gneiss and Namche Migmatites. Sometimes these granitic pools and pods locally carry tourmaline appearing to change into the tourmaline leucogranite. The granitic pools have no clear boundary with quartz-fedspathic bands of the host gneiss, and their elongated shape is either discordant or concordant with the banding/foliation.

In the Namche Bazaar area, varieties of migmatization phenomena and of their relationships with various small-scale structures are observed that provide critical data to interpret the process of the migmatization and granitic-leucogranitic activities.

Granitic pods, pools and bands, broadly referred here as leucosomes, generally follow the folds in the host gneiss (e. g., Figs. 4a-B, C, D, E). Thin granitic pools sometimes even form intrafolial isoclinal folds along with the banding of the host gneiss (Fig. 4a-E). An upright isoclinal fold observed at a locality west of Benkar is cut across by a biotite pegmatite dyke, which carry the schistosity nearly parallel to the axial plane of the fold (Fig. 4a-D). A migmatitic gneissose granite boulder observed at a locality south of Namche Bazaar carry a tightly folded thin layer composed of aggregate of potash feldspar and coarsegrained biotite, all are arranged parallel to the axial plane of the fold (Fig. 4b-B). This may indicate that an earlier granitic thin band suffered the tight-isoclinal folds during which the schistosity composed of coarse-grained biotite and flattened potash feldspar aggregates formed. At localities northeast of Khumjung, quartz-feldspar leucosome pods (large porphyroblasts) are distributed parallel to the gneissic banding and form tight folds, and the leucosome pods are flattened parallel to the axial surface of the fold (Figs. 4b-C) indicating that the tight fold might have formed during the main Himalayan metamorphism and that leucosome pods are earlier than the folding. It is not rare that the discordant arteritic veins and pools of granitic composition cut across intrafolially folded granitic bands.

Thus, the development of the granitic material is a result of migmatization in the HHCS. The time of the earlier migmatization could be older than the tight folds which formed during the main Himalayan metamorphism, and most possibly earlier than the intrafolial isoclinal fold and simultaneous with the formation of the gneissic banding. This idea conforms with the fact that the leucosomes are boudinaged along the thin banding and together suffered tight foldings (Fig. 4a-E). Goscombe et al. (2006) also reported that leucosomes are boudinaged along penetrative foliation in the HHCS. The occurrence of granitic veins and pools above could only be explained by repeated mobilization of the granitic rocks at different times, possibly from pre-Himalayan orogenies to the Miocene main Himalayan metamorphism. As discussed below, we consider the earliest formation of the granitic pools and pods (leucosomes) to have occurred during the early Paleozoic period.

Tourmaline leucogranite: The tourmaline leucogranite bodies occur extensively in all the rocks of the HHCS. It occurs locally as discordant dykes and veins, and as migmatitic granitic pools developing along the banding/foliation of the host gneiss. Occurrences of tourmaline leucogranite veins and pools occurring concordantly as well as discordantly with the tight folds are common. As a whole the occurrence of the leucogranite is very similar to that of the granitic pools mentioned above, although there is no observation that the leucogranite pools are isoclinally folded and further, no indication that they are earlier than the major schistosity forming event. The development of leucogranite pools and veins could be the result of migmatization of the HHCS during the late stage of the Miocene main Himalayan metamorphism.

\section{SAMPLE COLLECTION AND ISOTOPIC ANALYSIS}

\section{Analysed samples}

For the present study, two leucosome-bearing paragneiss samples from different horizons of the Namche Migmatites were collected. The first sample was collected from a lower horizon lying about $1 \mathrm{~km}$ north of Phakdin village situated on the right bank of the Dudhukoshi River (Fig. 2, Sample No. 07EVT3), the second sample (Sample No. U1206) was collected from a large cliff (Chipcho cliff) east of Khumjun village that lies to the northeast of Namche Bazaar.

Sample 07EVT3 is a migmatitic garnet-biotite paragneiss with sporadic leucosome pools and veins (Fig. 6a). Sample No. U1206, on the other hand, is a migmatitic sillimanite-garnetbiotite paragneiss with abundant leucosome pools and veins (Fig. 6b). The field occurrence and lithology of the two samples clearly show that both of these rocks are of sedimentary origin and that the leucosomes were formed during the high-grade metamorphism with associated migmatization. The zircons for the analysis were collected from leucosomes of the gneisses.

\section{U-Pb Analysis}

U-Pb geochronological studies of zircon grains collected from the HHCS gneiss samples were conducted using laser ablation-multicollector inductively coupled plasma-mass spectrometry (LA-MC-ICP-MS) at the University of Arizona, Tucson, USA following the methods reported by Gehrels et al. (2008) and Gehrels and Pecha (2014). The Concordia - discordia diagrams are shown in Figs.7a and $b$ and the analytical data are given in appendix table.

Analyses of zircons from Sample 07EVT3 (sample from the lower horizon) show that the U-Pb ages range from ca 525 to $20 \mathrm{Ma}$ with an exceptional age of ca $960 \mathrm{Ma}$ (Appendix 

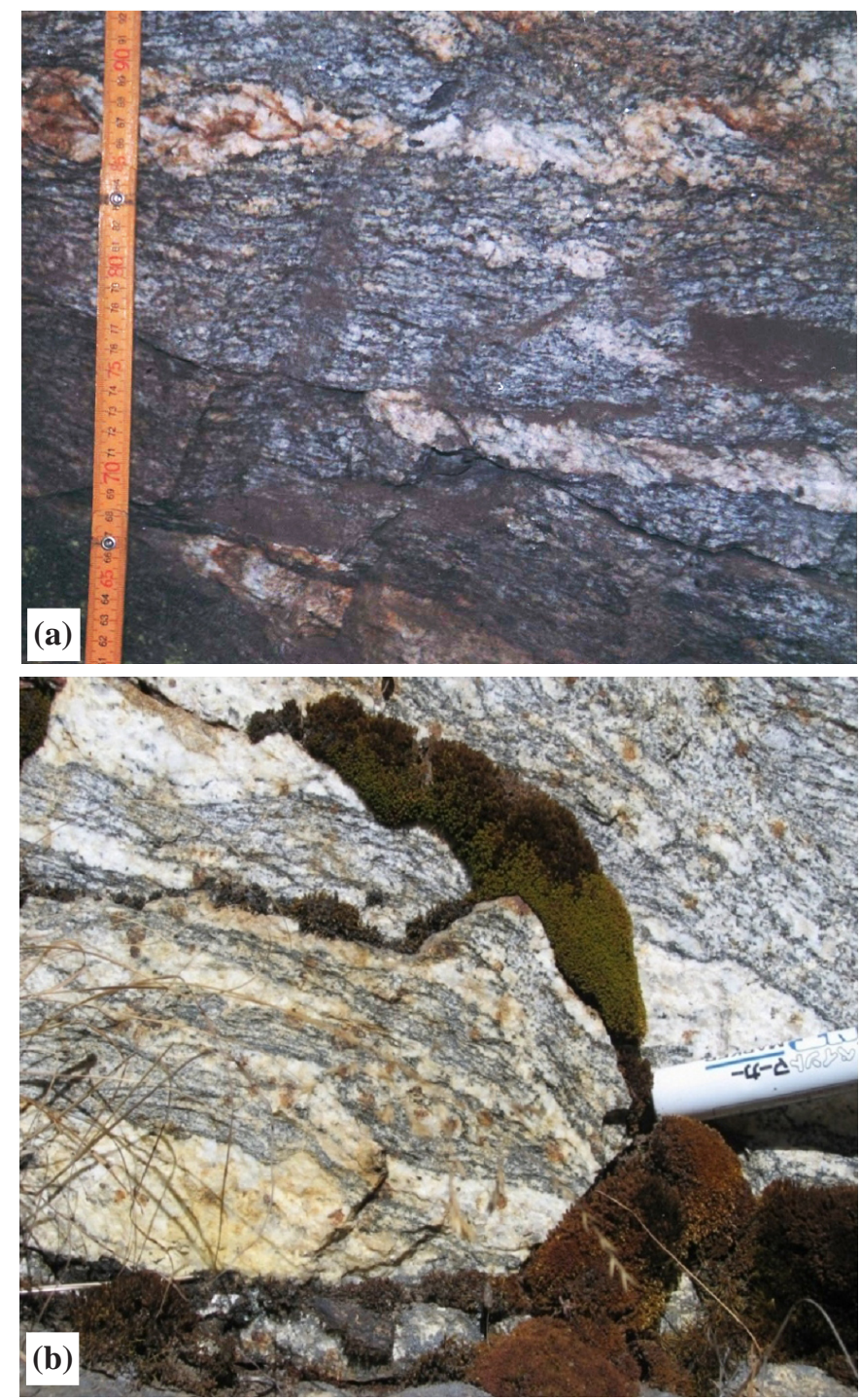

Fig. 6: (a) Sample No. 07EVT3, migmatitic garnet-biotite paragneiss, and (b) Sample No. 1206, migmatitic sillimanitegarnet-biotite paragneiss.

table). The U-Pb isotopic ratio are aligned on a discordia with upper and lower intercepts at $478 \pm 25$ and $21.5 \pm 4.1 \mathrm{Ma}$ (Fig. 7a). Among the total 38 analyses of zircons, 19 overlapping and concordant analyses of cores yield an average age of 488.5 $\pm 9.2 \mathrm{Ma}$, whereas 6 overlapping and concordant analyses of rims yield a weighted mean age of $20.9 \pm 0.9 \mathrm{Ma}$. The remaining 12 analyses, which are aligned on a discordia and yield discordant intermediate ages, are interpreted to show the loss of lead from the original Paleozoic zircons during the Miocene metamorphism.

$\mathrm{U}-\mathrm{Pb}$ ages of zircons from sample U1206 (sample from the upper horizon) range from ca 470 to $24 \mathrm{Ma}$, and the $\mathrm{U}-\mathrm{Pb}$ isotopic ratios are aligned on a discordia with upper and lower intercepts at $515 \pm 20$ and $34.8 \pm 2.7 \mathrm{Ma}$ (Fig. 7b). Among the total of 39 analyses of zircons, 2 concordant and overlapping analyses of cores give an average age of $463.9 \pm 10.9 \mathrm{Ma}$, whereas
12 overlapping and concordant analyses of rims yield an average age of $24.6 \pm 0.6 \mathrm{Ma}$. The remaining 25 analyses, which are aligned on a discordia and yield discordant intermediate ages, are interpreted to show the loss of lead from the original Paleozoic zircons during the Miocene metamorphism similar to zircons in the Sample 07EVT3.

\section{U-Th ratio of zircons}

The amount of $U$ in zircons of the samples 07EVT3 and U1206 range from 75 to $3450 \mathrm{ppm}$ with an average of $998 \mathrm{ppm}$ and from 1604 to $7855 \mathrm{ppm}$ with an average of $3811 \mathrm{ppm}$, respectively (Fig. 8). Similarly, the amount of Th in zircons of the sample 07EVT3 and U1206 range from 9 to $638 \mathrm{ppm}$ with an average of $133 \mathrm{ppm}$ and from 2 to $83 \mathrm{ppm}$ with an average of $19 \mathrm{ppm}$.

The U/Th ratios of zircons of the sample 07EVT3 range from 1.1 to 54.3 with an average of 11.0. The average of 17 analyses of zircons older than ca $290 \mathrm{Ma}$ is 10.1 and that of zircons younger than ca $32 \mathrm{Ma}$ is 21.4 (Appendix table). The U/Th ratio of zircons of the sample U1206 range from 76.8 to 1067.7 with the average of 253.6. Zircons from sample U1206 show no distinct difference in the U/Th ratio between the older
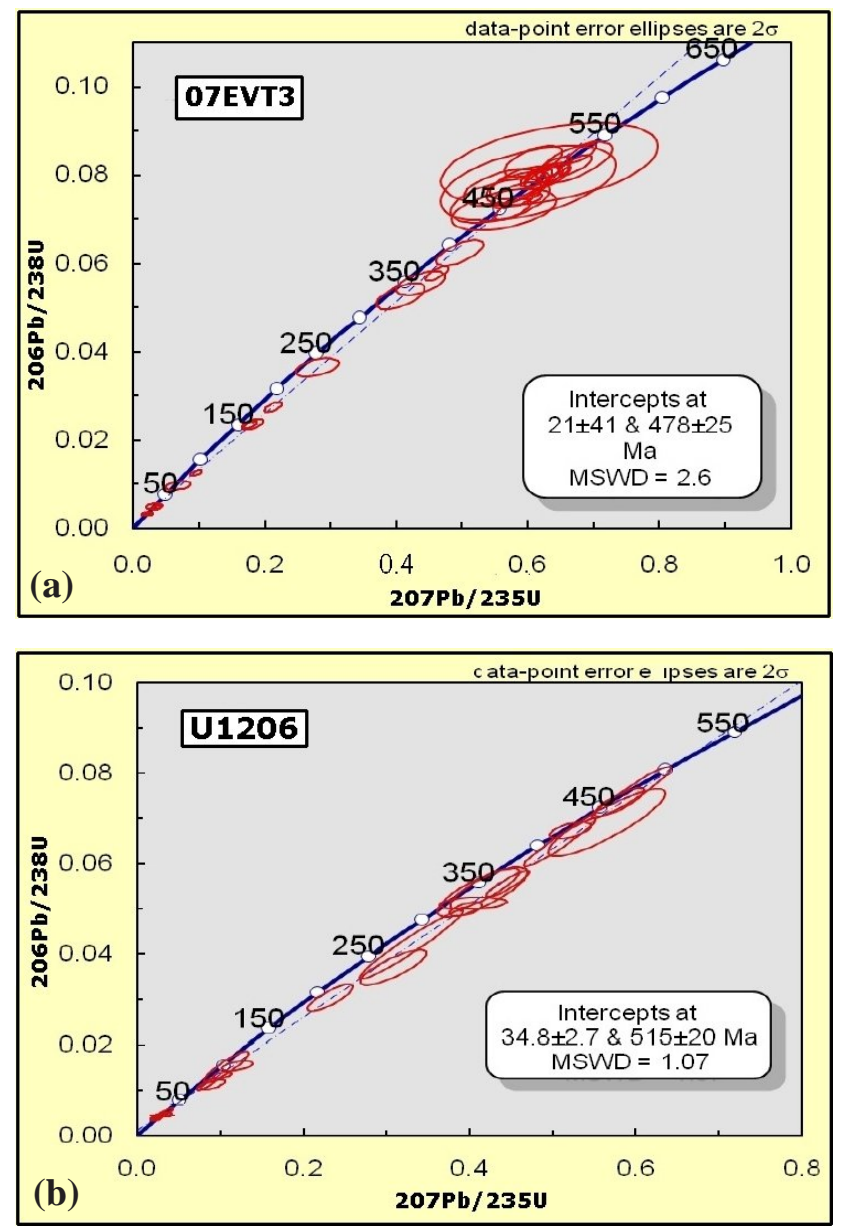

Fig. 7: (a)U-Pb analysis of zircons from sample 07EVT3, and (b) U-Pb analysis of zircons from sample U1206. 


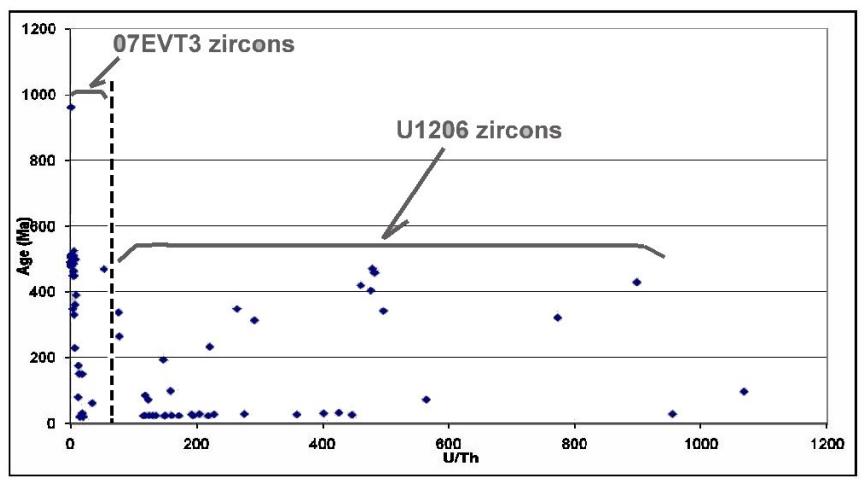

Fig. 8: U/Th plot of zircons from samples 07EVT3 and U1206

and younger zircons. Distinct difference in U/Th ratios between zircons of the two samples may be related to the compositional difference of the host rocks. High U/Th ratio (Fig. 8) found in the older as well as the younger zircons may suggest that they grew in the presence of abundant metamorphic fluids (Rubatto, 2017; Yakymchuk et al., 2018).

\section{PAN-AFRICAN TECTONICS IN THE NORTHERN MARGIN OF GONDWANALAND: DISCUSSION AND CONCLUSION}

\section{Chronology of metamorphism, migmatization, granitic activity and structures}

The rocks of the HHCS in the Everest region commonly show the development of superposed s-planes and foldings, as well as granitic pools and pods of various sizes as mentioned above. In the field, one can see the S0-S1 planes, rootless isoclinal folds, isoclinal-tight-close folds, foliation and schistosity, and sporadically developed gentle folds, cleavage and shear planes.

Granitic leucosomes often form the intrafolial rootless isoclinal folds as well as the isoclinal-tight-close folds. Some leucosome pools occur along the banding structure of banded gneiss and suffer extension along the banding and show a boudinage structure. The banding with boudinaged leucosomes pool as well as leucosomes band showing intrafolial rootless folds are folded by the isoclinal-tight-close folds. These field observations show that some leucosomes are much older than the isoclinal-tight-close folding event.

The penetrative foliation associated with the isoclinaltight-close folds is composed of flattened leucosome pods or potash feldspar porphyroblast and coarse crystals of biotite, which could be of the same generation as the widely developed penetrative foliation of the HHCS gneisses which are composed of flattened potash feldspar porphyroblast and/or elongated quartz-feldspathic aggregates and coarse-grained biotite associated with garnet and sometimes with sillimanite. Thus, the isoclinal-tight-close folds associated with the penetrative axial plane-parallel penetrative foliation is considered to be mostly synchronous with the main Himalayan metamorphism.

The shear planes are associated with fibrolite sillimanite in the HHCS and upper horizon of the LHS, and with chloritemuscovite mostly in the LHS, and cut across all other s-planes. Locally, tourmaline leucogranite develops along the shear planes.

Previous studies have shown that the Himalayan orogeny has experienced metamorphisms older than the main Himalayan metamorphism. They are the ultra-high-pressure metamorphism at ca $45 \mathrm{Ma}$ and the Eo-Himalayan high-P metamorphism at ca $33 \mathrm{Ma}$ as mentioned above. The metamorphism associated with migmatization under which leucosomes are generally formed is commonly attributed to the low-P high-T type main Himalayan metamorphism. Since the Cenozoic older metamorphisms than the main Himalayan metamorphism so far discovered are the high-P and ultra-high-P type, the metamorphism that formed the older leucosomes must therefore be the product of much older metamorphisms.

The occurrence of a large amount of early Paleozoic granitic rocks throughout the Himalayan orogen, that is regarded to have been generated by the crustal melting processes under the crustal thinning tectonics (Le Fort and Rai, 1999), could suggest the possibility that the leucosomes of the present study could be related to the formation of these early Paleozoic granites, in conjunction with a considerable part of leucosomes developed in rocks of the HHCS. The detection of early Paleozoic ages of zircons from leucosomes of two paragneisses in the present study, that suggests the age of the formation of the leucosomes to be early Paleozoic as discussed below, conforms with the above observation.

\section{Formative conditions and timing of the leucosomes}

Geochronology of zircons from leucosome pools has commonly been used to detect the age of a high-grade metamorphism in metamorphic terranes (e. g., Fitzsimons, 1997; Fraser et al., 2000), considering that those zircons should have formed during the leucosome formation, and that the leucosome is the product of high-grade metamorphism.

The present study invoking an early Paleozoic metamorphism based on zircon geochronology is built on the similar assumption as above. The leucosomes, from which the zircons for the geochronology were extracted, form one of leucosomes widely developed within the gneisses and thus are considered to be the product of migmatitic metamorphism of the gneisses. Zircons within the leucosomes have high U/Th ratios, averaging both averages of 253.6 for zircons in the sample U1206 and 11.0 for zircons in the sample 07EVT3, almost definitely pointing their metamorphic origin (Rubatto, 2017; Yakymchuk et al., 2018).

Ca 500 Ma old zircons from the sample U1206 cannot be considered as the inherited zircons of detrital origin since there are no older zircons than ca $500 \mathrm{Ma}$ has been detected in the sample. It is because the HHCS rocks commonly carry high 
population of older zircons than ca $500 \mathrm{Ma}$. (e.g., review by Yoshida and Upreti, 2004). Thus, the ca 500 Ma ages of zircons from the Namche Migmatites (samples U1206 and 07EVT3) are considered to be the age of the metamorphism under which the leucosomes were formed under high-T and low-P metamorphic conditions producing the migmatites.

Zircons with ca $500 \mathrm{Ma}$ and older ages from Sample 07EVT3 could either be metamorphic or detrital in origin, first because ca 960 Ma zircons of obviously detrital origin is found (Appendix table), and second because the U/Th ratio is mostly 1.1-9.7, which is generally of the metamorphic zircons, but also rarely found in igneous zircons (Yakymchuk et al., 2018). However, the U/Th ratio of rim zircons from the same leucosome is around 20. Even though U/Th ratio is only 20, which is low compared to that of younger zircons from U1206, it is obviously of metamorphic origin since the host rock is paragneiss of Early or Middle Cambrian age, and zircons occur in leucosomes and mostly forming rims around older zircons. So far as the rim zircons of the Miocene metamorphic origin have low U/Th ratio in the sample 07EVT3, the low U/Th ratio of older zircons could not necessarily be considered as non-metamorphic origin. The relatively low U/Th ratios of both rim and core zircons in the sample 07EVT3 could reflect a chemical characteristic of the host rock (sample 07EVT3). Considering all the above conditions, ca 500 Ma zircons in leucosomes of sample 07EVT3 could have two generations. Some relatively older ages than ca 500 Ma may be of inheritance origin, and others could be mostly of metamorphic origin formed during a ca 500 Ma metamorphism and suffered lead loss during the Miocene main Himalayan metamorphism.

The above results clearly point out that a considerable amount of zircon grains in the analyzed samples initially formed during the early Paleozoic time and later suffered $\mathrm{Pb}$ loss later during the Miocene time. The occurrence of zircons within leucosomes of gneisses indicates that these zircons must have developed during the formation of these leucosomes, thus precisely indicating the time of the high-grade metamorphism and migmatization resulting in the formation of the leucosomes, during the early Paleozoic time.

The complete absence of inherited zircons older than ca $500 \mathrm{Ma}$ in sample U1206 could be explained in two ways. One explanation is that all zircons are new and must have formed during the leucosome formation. Alternatively, the high-grade metamorphism with associated hot fluids must have completely re-equilibrated all the inherited zircons as was the case elsewhere in some high-grade metamorphic terranes (e. g., Yoshida and Upreti, 2006; Siebel et al., 2012).

\section{Miocene main Himalayan metamorphism}

Zircons with concordant Miocene ages from sample 07EVT3 and U1206 must have either formed as a new mineral or derived from completely re-equilibrated older zircons during the Miocene main Himalayan metamorphism. The measurement of discordant ages aligned on a discordia connecting ca 478-
$515 \mathrm{Ma}$ and ca 21-35 Ma ages of zircons indicate that at least a part of concordant Miocene ages is due to re-equilibration of the older zircons. The rim zircons from both samples are obviously of metamorphic origin, because the ages are far younger than the age of the original rock deposition and also because they grow along the rim of older zircons. The ages of metamorphism indicated by the concordant zircon ages of 20.9 $\pm 0.9 \mathrm{Ma}$ of rim zircons from sample 07EVT3 and 24.6 \pm 0.6 Ma of rim zircons from sample U-1206 well coincide with the so far published ages of the main Miocene Himalayan metamorphism (Simpson et al., 2000; Viskupic and Hodges, 2001 ), among which the age of $24.6 \pm 0.6$ Ma could be the early stage of the main Himalayan metamorphism and the age of 20.9 $\pm 0.9 \mathrm{Ma}$ appears to point the migmatitic metamorphism associated with the formation of tourmaline leucogranite, at the later stage of the main Himalayan metamorphism.

The leucosomes of both locations from where the samples were collected for geochronological work appear to be partly parallel and partly discordant to the banding/foliation of the host gneisses, thus appearing to be relatively of younger age, even though the leucosomes are considered to have initially formed during the early Paleozoic as mentioned above. This duel structural relationship of the leucosomes may have developed as a result of the remobilization /re-melting of the older (early Paleozoic) leucosomes during the Miocene metamorphic event. This explanation is corroborated by the extensive occurrence of zircons of Miocene age as well as the clear discordia of $\mathrm{U}-\mathrm{Pb}$ analyses of zircons with the lower intercept ages of 21.4+/-4.1 Ma and 34.8+/-2.7 Ma. The lower intercept age of $34.8 \pm 2.7 \mathrm{Ma}$ is within the age range of the EoHimalayan high-P metamorphism regarded to have developed throughout the Himalayan orogen as mentioned above, and therefore could indicate the lead loss in zircons by the metamorphism of this age.

\section{The Pan-African orogeny in the Proto-Himalayan Belt}

The early Paleozoic timing of metamorphism of the Higher Himalayan Gneisses has been exemplified by a variety of studies (e. g., Stocklin, 1980; Argles et al., 1999; Marquer et al., 2000; Gehrels et al., 2006a, b; Cawood et al., 2007). Robust field evidence of the Pan-African metamorphism is the crosscut relationship of the Pan-African granite with the country rock of the Higher Himalayan gneiss reported from the Kathmandu and surrounding areas (Stocklin, 1980; Gehrels et al., 2006a; Cawood et al., 2007) as well as from the Himachal Himalaya (Marquer et al., 2000). Related evidence providing critical geochronological constraints was also reported by some of the above authors.

Wide occurrences of the sedimentological hiatus and distinct unconformity/disconformity during the early Paleozoic time have also been known and pointed out as the evidence of the late Pan-African orogeny in the Himalaya (e. g., Garzanti et al., 1986; Valdiya, 1995). This stratigraphic event is nearly in harmony with the unconformity over the Purana rocks recognized throughout the Indian Subcontinent (Valdiya, 1995). 
Further, there are extensive occurrences of late PanAfrican granitoids in the Lesser Himalayan and Higher Himalayan zones (e.g., Le Fort et al., 1986; Le Fort and Rai, 1999; Gehrels al., 2006a, 2006b). Geochemically, these granitoids are mostly peraluminous to aluminous, S-type and with withinplate signature. Their ages are generally in the range of 490 $\pm 20 \mathrm{Ma}$ to $480 \pm 11 \mathrm{Ma}$ (Gehrels et al., 2006a), suggesting the late Pan-African orogenic event that caused the crustal melting processes. The process of crustal melting associated with granitic rock formation could have been associated with the high-T/lowP migmatitic metamorphism.

Thus, it can be strongly argued that the Pan-African orogeny associated with high-grade metamorphism took place in the Proto-Himalayan Belt. The structural domains of the Proto Himalayan Belt situated at the northern margin of the Indian craton during the early Paleozoic (Fig. 9) can be estimated from the Proterozoic geology of northern India, the common zonal structure of the Himalayan Belt including the early Paleozoic Tethys Sequence and granitoid bodies, and the age distribution of detrital zircons from the Himalayan rocks (Myrow et al., 2003). The intracratonic signature or the peri continental signature of the orogen is possible judging from the lack of ophiolite as well as the flysch sediments, and the predominance of S-type granitic activities since late Neoproterozoic to Paleozoic, as stressed by Le Fort and Rai (1999) and Marquer et al. (2000).

\section{The Peri-Gondwana orogenic Belt}

There was a major diversity in opinions regarding the tectonic signature of the Proto Himalayan orogeny; whether it was extensional or constrictional. Le Fort et al. (1986) and Le Fort and Rai (1999) considered the crustal thinning for the origin of the early Paleozoic granitoids in the Nepal Himalaya. This corroborates with the structural style including tilting and gentle folding of the lower Tethys sequence as pointed out by Valdiya (1995). These observations lend support that the orogeny was of the upwelling-rifting type under the extensional tectonic regime.

DeCelles et al. (2000) and Gehrels et al. (2006a), however, proposed a constrictional orogeny (south-vergent) from general understandings on lithostratigraphy and large-scale geologic structures, which was also supported by Upreti and Yoshida (2005) from field observation of mesoscopic structures in rocks of the lowest horizon of the TTSS.

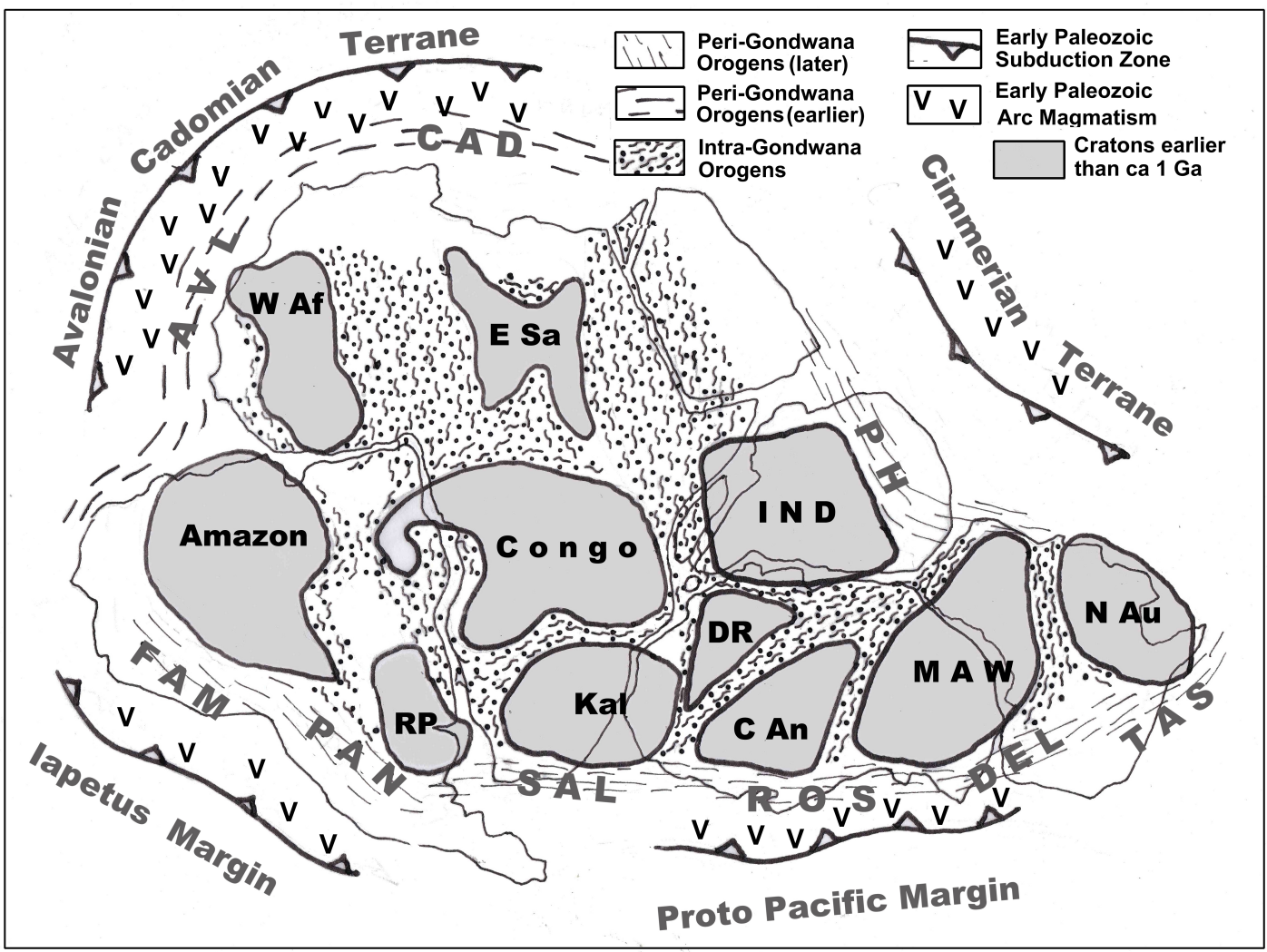

Fig. 9: Location of the Proto-Himalayan Orogen (PH) in assembled Gondwanaland during the early Paleozoic time.

PH: Proto-Himalayan Orogen, TAS: Tasmanian Orogen, DEL: Delamerian Orogen, ROS: Ross Orogen, SAL: Saldanian Orogen, PAN: Panpean Orogen, FAM: Famatinian Orogen, AVL: Avalonian Orogen, CAD: Cadomian Orogen. Base Gondwanaland figure is referred to Unrug (1997). Tectonic characterization of peril-Gondwana terranes are mostly referred after Cawood et al. (2007), Ding et al. (2015), Fernandez et al. (2010), Goodge (2002), Hajna et al. (2017), Jaillard et al. (2000), Murphy et al (2010), Reimann et al. (2010), Rapela (2000) and Torsvik et al (2009) 
All the above observations and ideas may suggest that the Proto-Himalayan Belt suffered both constrictional and extensional tectonics during the late Pan-African time, as were the cases in Avalonian-Cadomian (Fernandez et al., 2010) and Proto-Pacific (Goodge, 2002) margins of Gondwana and thus altogether appear to form the Peri-Gondwana orogenic belts.

The field evidence that shows a Pan-African granite cutting across well-foliated Higher Himalayan gneiss (e. g., Marquer et al., 2000) appears to suggest that the constrictional tectonics predates the extensional one. It is noteworthy that Garzanti et al. (1986) indicated the immature island arc environment for the Proto-Himalayan Belt based on the occurrence of low-K tholeiitic tuff layer in the lower Paleozoic formations, and Ding et al. (2015) suggested an Andean type orogeny along the northern margin of Gondwana based on the occurrence of ultrapotassic rhyolites of 512 Ma from the Lhasa terrane. These observations provide the idea of incorporating the subduction and arc activity model on the Proto-Himalayan Orogeny. It could naturally cause to form a tectonic model starting from a passive margin environment (late Neoproterozoic) followed by subduction, arc activity and metamorphism under the constrictional tectonic regime (Cambrian) which were succeeded by the back-arc extension with a large amount of granite intrusions (end Cambrian-Ordovician).

A general tectonic characteristic of the Peri-Gondwana orogens was pointed out by some authors (e. g., Unrug, 1997; Cawood et al., 2007; Yoshida and Upreti, 2014). A general timing of the Peri-Gondwanan orogeny, that it took place after the amalgamation of Gondwana through the Intra-Gondwana orogenies of mostly during the late Neoproterozoic time, and that it occurred mostly during the early Paleozoic time has been pointed out by the above authors. Provisional figures of some sectors of the Peri-Gondwana orogenic belts have been shown by Cawood et al. (2007), Fernandez et al. (2010), Hajna et al. (2017), Goodge (2002) and Torsvik et al. (2009). Cawood et al. (2007) figured out a tectonic characterization of the ProtoHimalayan Orogeny (their Bimphedi orogeny) considering a variety of geologic information so far available.

It is obvious that the Proto-Himalayan Orogen is the only orogen on the northern margin of Gondwana where practical field studies are possible. Further petrological and structural studies of the early Paleozoic events in the Himalaya will provide a realistic figure of the Proto-Himalayan Orogen, and will form important contributions to improve the understanding of tectonic processes of the Peri Gondwanan orogens.

\section{REFERNCES}

Akiba, C., Amma, S., and Ohta, Y., 1973, Arun River Region. In Ohta, Y. and Akiba, C. (Eds.), Geology of the Nepal Himalaya. Himalayan Committee of Hokkaido University, Saikon Pub. Co., Tokyo, pp. 13-33.

Argles, T.W., Prince, C.I., Foster, G.L., and Vance, D., 1999,
New garnets for old? Cautionary tales from young mountain belts. Earth and Planetary Science Letters, v. 172, pp. 301-309.

Bortolami, G.C., Lombardo, B., and Polino, R., 1983, The granites of the upper Imja Khola (Everest region), eastern Nepal. In: Shams, F.A. (Ed.), Granites of Himalaya Karakorum and Hindu-Kush. Punjab Univ., Lahor, Pakistan, pp. 257-3270.

Carosi, R., Lombardo, B., Musumeci, G., and Pertusati, P.C., 1999, Geology of the Higher Himalayan Crystalines in Khumbu Himal (Eastern Nepal). Jour. Asian Earth Sci., v. 17, pp. 785-3803.

Carosi, R., Montomoli, C., Laccarino, S., Massonne, H-J., Rubatto, D., Langone A., Gemignani, L., and Visona, D., 2016, Middle to late Eocene exhumation of the Greater Himalayan Sequence in the Central Himalayas: Progressive accretion from the Indian plate. GSA Bull., v. 128, pp. 1571-1592.

Cawood, P. A., Johnson, R.M.R.W., and Nemchin, A.A; 2007, Early Palaeozoic orogenesis along the Indian margin of Gondwana: Tectonic response to Gondwana assembly. Earth and Planetary Sci. Let., v. 255,1 pp. 70-64.

DeCelles, P.G., Gehrels, G.E., Quade, J., Reau, B., and Spurlin, M., 2000, Tectonic implications of U-Pb zircon ages of the Himalayan orogenic belt in Nepal. Science, v. 228, pp. 497-499.

Ding, H., Zhang, Z, Dong, X., Yan, R., Lin, Y., and Jiang, H., 2015, Cambrian ultrapotassic rhyolites from the Lhasa terrane, south Tibet: Evidence for Andean-type magmatism along the northern active margin of Gondwana. Gondwana Research, v. 27, pp. 1616-1629.

Edwards, M.A. and Harrison, T.M., 1997, When did the roof collapse? Late Miocene north-south extension in the high Himalaya revealed by $\mathrm{Th}-\mathrm{Pb}$ monazite dating of the Khula Kangri granite. Geology, v. 25, pp. 543-546.

Fernandez, R.D., Catalan, M.J.R., Gerdes, A., Abati, J., Arenas, R., and Fernandez-Suarez, J., 2010, U-Pb ages of detrital zircons from the Basal allochthonous units of NW Iberia: Provenance and paleoposition on the northern margin of Gondwana during the Neoproterozoic and Paleozoic. Gondwana Research, v. 18, pp. 385-399.

Fitzsimons, I.C.W., 1997, The Brattstrand Paragneiss and the Sostrene Orthogneiss: a review of Pan-African metamorphism and Grenvillian relicts in southern Prydz Bay. In: Ricci, C.A. (Ed.), The Antarctic Region: Geological Evolution and Processes. Terra Antarctica Pub., Siena, pp. 121-130.

Fraser, G., McDougall, I., Ellis, D.J., and Williams, I.S., 2000, Timing and rate of isothermal decompression in PanAfrican granulites from Rundagschetta, East Antarctica. Jour. Metamorphic Geol., v. 18, pp. 441-454. 
Garzanti, E., Casnedi, R., and Jadoul, F., 1986, Sedimentary evidence of a Cambro-Ordovician orogenic event in the northwestern Himalaya. Sedim. Geol., v. 48, pp. 237-265.

Gehrels, G.E. and Pecha, M., 2014, Detrital zircon U-Pb geochronology and Hf isotope geochemistry of Paleozoic and Triassic passive margin strata of western North America. Geosphere, v. 10 (1), pp. 49-65.

Gehrels, G.E., DeCelles, P.G., Martin, A., Ojha, T.P., Pinhassi, G., and Upreti, B.N., 2003, Initiation of the Himalayan Orogen as an early Paleozoic thin-skinned thrust belt. GSA Today, September 2003, pp. 4-9.

Gehrels, G.E., DeCelles, P.G., Ojha, T.P., and Upreti, B.N., 2006a, Geologic and U-Th-Pb geochronologic evidence for the early Paleozoic tectonics in the Kathmandu thrust sheet, central Nepal Himalaya. GSA Bull., v. 118, pp. 185-198. doi: 10.1130/B25753.1; 14 figures; Data Repository item 2006016.

Gehrels, G.E., DeCelles, P.G., Ojha, T.P., and Upreti, B.N., 2006b, Geologic and U-Pb geochronologic evidence for early Paleozoic tectonism in the Dadeldhura thrust sheet, far-west Nepal Himalaya. Journal of Asian Earth Sciences, v. 28, pp. 385-408.

Gehrels, G.E., Valencia, V.A., and Ruiz, J., 2008, Enhanced precision accuracy, efficiency, and spatial resolution of $\mathrm{U}-\mathrm{Pb}$ ages by laser ablation-multicollector-inductively coupled plasma-mass spectrometry, Geochemistry, Geophysics, Geosystems. v. 9(3), doi org/10.1029/2007GC001805.

Goscombe, B., Gray, D., and Hand, M., 2006, Crustal architecture of the Himalayan metamorphic front in eastern Nepal. Gondwana Research, v. 10, pp. 232-255.

Goodge, J.W., 2002, From Rodinia to Gondwana: supercontinent evolution in the Transantarctic Mountains. Royal Society of New Zealand Bull., 35 (Antarctica at the close of a millennium), pp. 61-74.

Hajna, J., Zak, J., Dorr, W., 2017, Time scales and mechanisms of growth of active margins of Gondwana: A model based on detrital zircon ages from the Neoproterozoic to Cambrian Blovice accretionary complex, Bohemian Massif. Gondwana Research, v. 42, pp. 63-83.

Jaillard, Herail, G, Monfret, T., Diaz-Martinez, E., Baby, P. Lavenu, A., and Dumont, J.F., 2000, Tectonic evolution of the Andes of Ecuador, Peru, Bolivia and Northernmost Chile. In Cordani, U.G. et al. (eds.), Tectonic Evolution of South America, Rio Ede Janeiro, pp. 481-559.

Kaneko, Y., Katayama, I., Yamamoto, H., Misawa, K., Rehman, H.U., Kausac, A.B., and Shiraishi, K., 2003, Timing of Himalayan ultrahigh-pressure metamorphism: Sinking rate and subduction angle of the Indian continental crust beneath Asia. Jour. Metamorphic Geol., v. 21, pp. 589-559.

Le Fort, P., 1975, Himalayas: the collided range. Present knowledge of the continental arc. Am. Jour. Sci., v. 275, pp. 1-44.
Le Fort, P., Debon, F., Pecher, A., and Sonet, J.V.P., 1986, The 500 Ma magmatic event in Alpine southern Asia, a thermal episode at Gondwana scale. In Le Fort, P. and others (Eds.), Evolution des domaines orogeniques d'Asie meridionale. v. 47. Sci. de la Terre, Nancy, pp. 191-209.

Le Fort, P. and Rai, S.M., 1999, Pre-Tertiary felsic magmatism of the Nepal Himalaya: recycling of continental crust. Jour. Asian Earth Sciences, v. 17, pp. 607-628.

Lombardo, B., Pertusati, P., and Borghi, S., 1993, Geology and tectonomagmatic evolution of the eastern Himalaya along the Chomolungma-Makalu transect. In: Treloar, P.J., Searle, M.P. (Eds.), Himalayan Tectonics. Geol. Soc., Special Publication, v. 74, pp. 323-340.

Marquer, D., Chawla, H.S., and Challandes, N., 2000, PreAlpine high-grade metamorphism in the High Himalaya crystalline sequences: evidence from Lower Palaeozoic Kinnaur Kailas granite and surrounding rocks in Sutlej Valley (Himal Pradesh, India). Eclogae Geologicae Helvetica, v. 93, pp. 207-220.

Montomoli, C., Iaccarino. S., Carosi, R., Langone, A., and Visona, D., 2013, Tectonometamorphic discontinuities within the Greater Himalayan Sequence in western Nepal (central Himalaya): Insights on the exhumation of crystalline rocks. Tectonophysics, v. 608, pp. 1349-1370.

Murphy, J.B., Keppie, J.D., Nance, R.D., Dostal, J., 2010, Comparative evolution of the Iapetus and Rheic Oceans: A North America perspective. Gondwana Research, 17, 482-499.

Myrow, P.M, Hughes, N.C., Paulsen, T.S., Williams, I.S., Parcha, S.K., Thompson, K.R., Bowring, S.A., Peng, S.C., and Ahluwalia, A.D., 2003, Integrated tectonostratigraphic analysis of the Himalaya and implications for its tectonic reconstruction. Earth and Planetary Science Let., v. 212, pp. 433-4471.

Myrow, P.M., Snell, K.E., Hughes, C, Paulsen, T.S., Heim, N.A., and Parcha, S.K., 2006, Cambrian depositional history of the Zanskar Valley region of the Indian Himalaya: Tectonic implications. Jour. Sedim. Res., v. 76, pp. 364-381.

Myrow, P.M., Hughes, N.C., Searle, M.P., Fanning, C.M., Peng, S.C., and Parcha, S.K., 2009, Stratigraphic correlation of Cambrian Ordovician deposits along the Himalaya: Implications for the age and nature of rocks in the Mount Everest region. Geol. Soc. Am. Bull., v. 121, pp. 323-332.

Rai, S.M., Yoshida, M., Upreti, B.N., Bhattarai, T.N., Ulak, P.D., and Koirala, M.P., 2010, Geology of the Everest Area, Eastern Nepal Himalaya. Nepal Academy of Sci. Tech., Kathmandu, pp. 45-55.

Rapela, C. W., 2000, The Sierras Pampeanas of Argentina; Paleozoic building of the southern proto-Andes. In: Cordani, U. et al. (Eds.), Tectonic Evolution of South America, Rio de Janeiro, pp. 381-387. 
Reimann, C.R., Bahalburg, H., Koojiman, E., Berndt, J., Gerdes, A., Carlotto, V., and Lopez, S., 2010, Geodynamic evolution of the early Paleozoic Western Gondwana margin $140-17$ oS reflected by the detritus of the Devonian and Ordovician basins of southern Peru ad northern Bolivia. Gondwana Research, v. 18, pp. 370-384.

Robinson, D.M., DeCelles, P.G., Garzione, C.N., Pearson, O.N., Harrison, T.M., and Catlos, E.J., 2001, The kinematic evolution of the Nepalese Himalaya interpreted from d isotopes. Earth Planet. Sci. Lett., v. 192, pp. 507-521.

Rubatto, D., 2017, Zircon: The metamorphic mineral. Review in Mineralogy and Geochemistry, v. 83, pp. 261-295.

Sakai, H., Sawada, M., Takigami, T., Orihashi, Y., Danhara, T., Iwano, H., Kuwahara, Y., Dong, Q., Cai, H., and Li, J., 2005, Geology of the summit limestone of Mount Qomolangma (Everest) and cooling history of the Yellow Band under the Qomolangma detachment. The Island Arc, v. 14, pp. 297-310.

Schelling, D., 1999, Geological map of the eastern Nepal Himalaya (scale 1:650,000). In: Le Fort, P., Upreti, B.N. (Eds.), Geology of the Nepal Himalaya: Recent Advances: Jour. Asian Earth Sci., v. 17, pp. 577-606.

Searle, M.P., Simpson, R.L., Law, R.D., Parrish, R.R., and Waters, D.J., 2003, The structural geometry, metamorphic and magmatic evolution of the Everest massif, High Himalaya of Nepal-South Tibet. Jour. Geol. Soc., London, v. 160 , pp. 345-366.

Searle, M.P., Stephenson, B.J., Walker, J.D., and Walker, C.B., 2007, Restoration of the western Himalaya: Implications for metamorphic protoliths, thrust and normal faulting, and channel flow models. Episodes, v. 30 (4), pp. 242-257.

Siebel, W., Shang, C.K., Thern, E., Danisik, M., and Rohrmuller, J., 2012, Zircon response to high-grade metamorphism as revealed by $\mathrm{U}-\mathrm{Pb}$ and cathodoluminescence studies. Int. J. Earth Sciences (Geol. Rundsch), DOI 10.1007//s00531-012-0772-5, total 19 pages.

Simpson, R.L., Raters, D.J., Searle, M.P., and Waters, D.J., 2000, Two episodes of monazite crystallization during metamorphism and crustal melting in the Everest region of the Nepalese Himalaya. Geology, v. 28(5), pp. 403-406.

Stöcklin, J., 1980, Geology of Nepal and its regional frame. Geological Society (London) Journal, v. 137, pp. 1-34.

Torsvik, T.H., Paulsen, T.S., Hughes, N.C., Myrow, P.M., and Ganerod, M., 2009, The Tethyan Himalaya: palaeogeographical and tectonic constraints from Ordovician palaeomagnetic data. Jour. Geol. Soc., v. 166, pp. 679-687.

Unrug, R., 1997, Rodinia to Gondwana: the geodynamic map of Gondwana supercontinent assembly. GSA Today, v. 7, pp. 1-6.

Upreti, B.N. and Yoshida, M., 2005, Guidebook for Himalayan
Trekkers, Ser. 1. Geology and Natural Hazards along the Kaligandaki Valley, Nepal. Special Publication 1, Dept. Geology, Trichandra Campus, Tribhuvan University, Kathmandu, 165p.

Valdiya, K.S., 1995, Proterozoic sedimentation and Pan-African geodynamic development in the Himalaya. Precambrian Research, v. 74, pp. 35-55.

Viskupic, K. and Hodges, K.V., 2001, Monazite-xenotime thermochronometry: methodology and an example from the Nepalese Himalaya. Contrib. Mineral. Petrol., v. 141, pp. 233-247.

Yakymchuk, C., Kirkland, C.L., and Clark, C., 2018, Th/U ratios in metamorphic zircon. Jour. Metamorphic Geol., v. 14, pp. 1-23.

Yin, C.-H. and Kuo, S.-T., 1978, Stratigraphy of the Mount Jolmo Lungma and its north slope. Science Sinica, v. 21, pp. 629-644.

Yoshida, M. and Upreti, B.N., 2004, Commentary on the position of Himalayan basement in Gondwanaland. Abstracts. 19th Himalaya-Karakoram-Tibet Workshop, HKT19, July 1012, 2004, Niseko, Himalayan Jour. Sci., v. 2, 286p.

Yoshida, M. and Upreti, B.N., 2006, Neoproterozoic India within East Gondwana: Constraints from recent geochronologic data from Himalaya. Gondwana Research, v. 10, pp. 349-356.

Yoshida, M. and Upreti, B.N., 2007, Commentary on the PanAfrican orogeny in the Himalaya (Abstract), 4th Intn'l Symp. Gondwana to Asia, IAGR Conference Ser. 4, 191-193.

Yoshida, M. and Upreti, B.N., 2011, Review of detrital zircon age and Sm-Nd isotopic data from Himalaya: Support to the Mesoproterozoic formation of East Gondwana. Jour. Nepal. Geol. Soc., v. 43, pp. 29-36.

Yoshida, M. and Upreti, B.N., 2014, Late Pan-African PeriGondwana orogens: extending the Proto-Himalayan Belt. Presented at The Second Symposium on Polar Science, Tachikawa, Japan.

Yoshida, M., Upreti, B.N., DeCelles, P.G., Gehrels, G.E., and Ojha, T.P., 2006, Basement history and provenance of the Tethys sediments of the Himalaya: An appraisal based on recent geochronologic and tectonic data. Bull. Tethys Geol. Soc., Cairo, v. 1, pp. 1-6.

Yoshida, M., Upreti, B.N., and Rai, S.M., 2011, Ecotrekking in the Everest Region, Eastern Nepal: Geology and Environment along the Lukla-Everest Base Camp and Namche-Gokyo Routes, Geology and Natural Hazards along the Dudhkoshi valley, Everest area. Guidebook for Himalayan Trekkers, Ser. 2, Department of Geology, TriChandra Campus, Tribhuvan University, Nepal. 192p. 


\section{Appendix}

\section{U-Pb-Th analytical data for U-Pb geochronology}

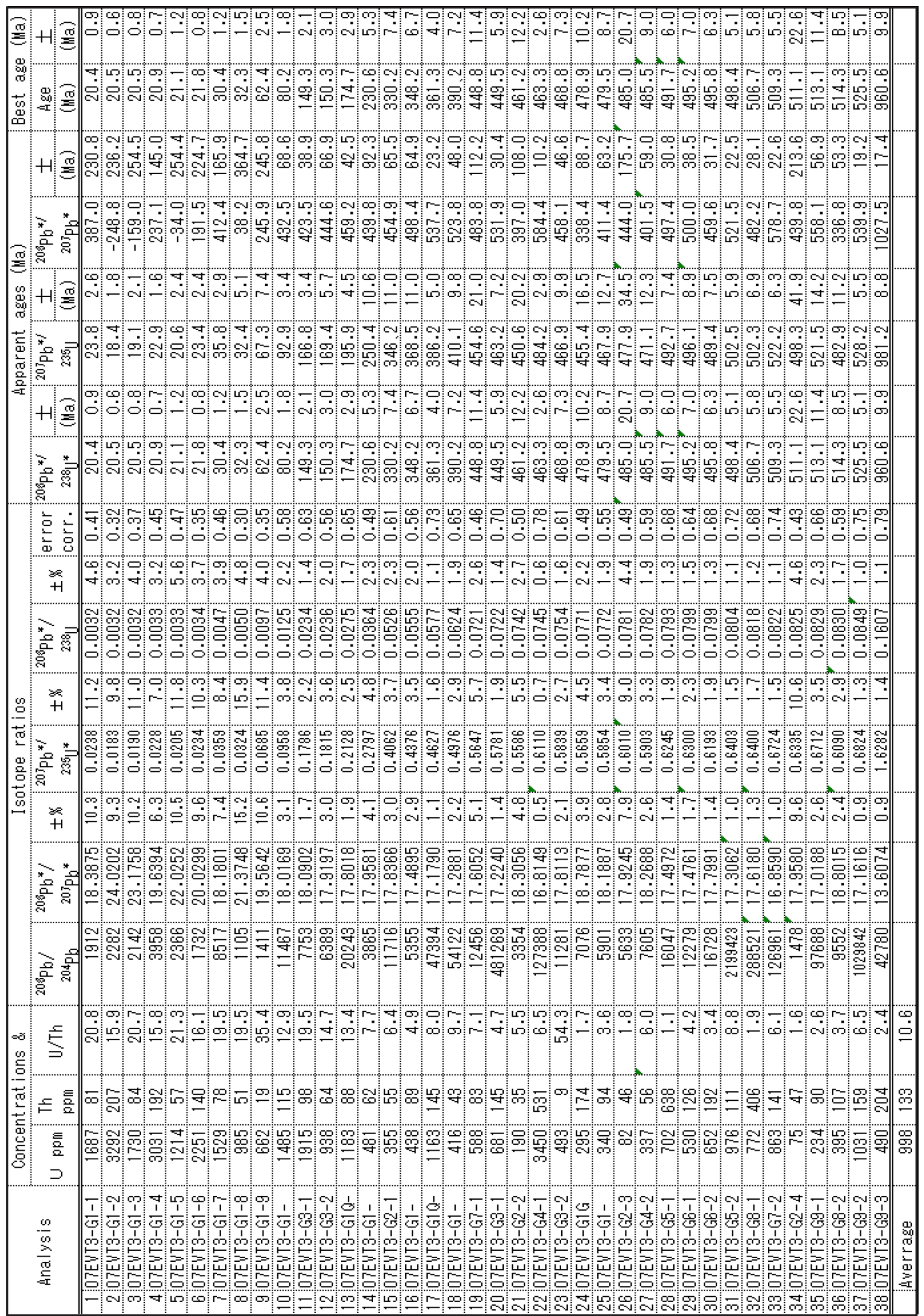




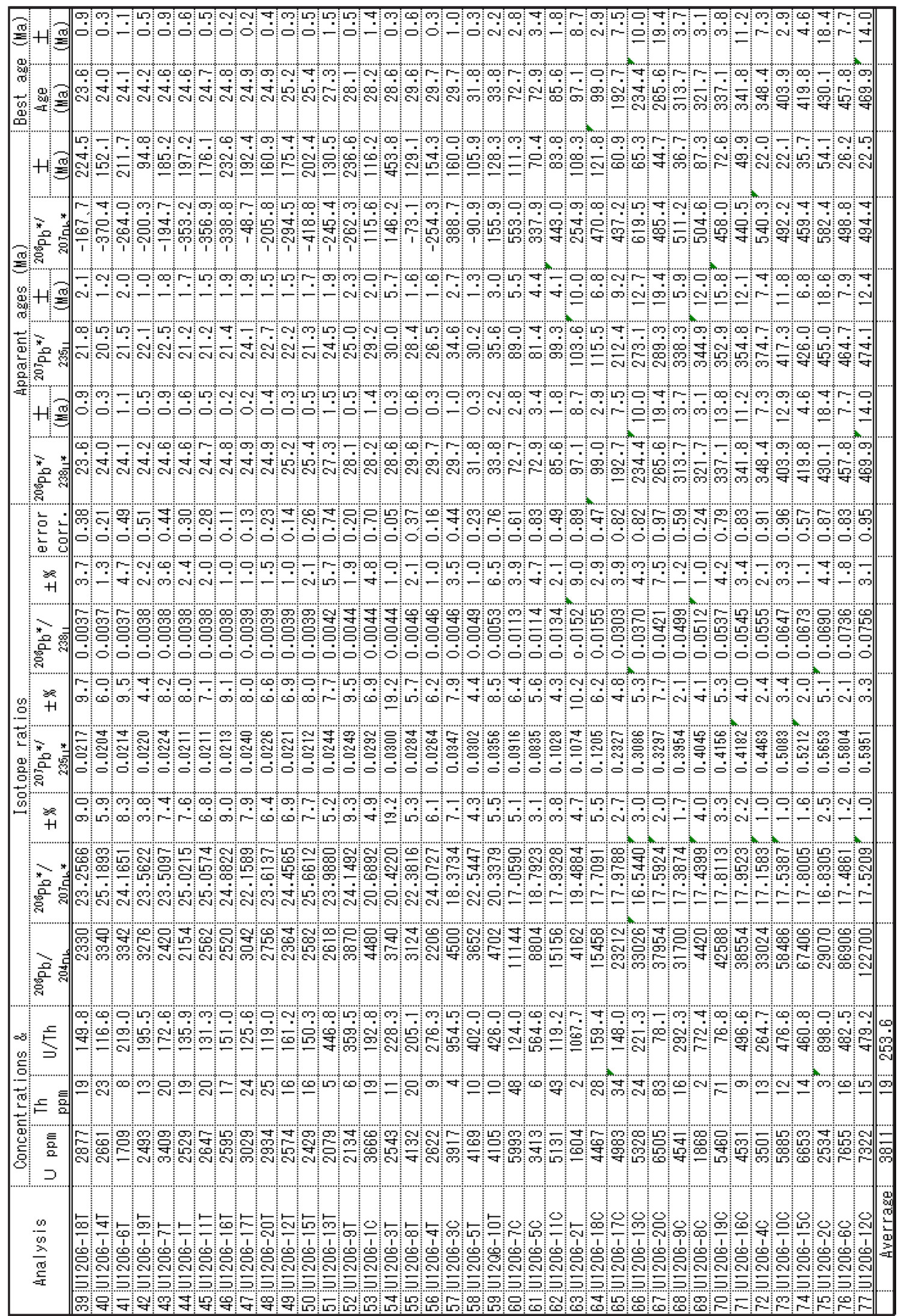

